\title{
Inconsistent magnetic polarities in magnetite- and greigite-bearing sediments: Understanding complex magnetizations in the late Messinian in the Adana Basin (southern Turkey)
}

\section{Stella Lucifora and Francesca Cifelli}

Dipartimento di Scienze Geologiche, Università Roma Tre, Largo San Leonardo Murialdo 1, IT-00146 Rome, Italy (stella.lucifora@gmail.com; cifelli@uniroma3.it)

\section{Massimo Mattei \\ Dipartimento di Scienze Geologiche, Università Roma Tre, Largo San Leonardo Murialdo 1, IT-00146 Rome, Italy}

Also at Istituto di Geologia Ambientale e Geoingegneria, Area della Ricerca Roma 1 Montelibretti, Via Salaria Monterotondo Scalo, IT-00016 Rome, Italy (mattei@uniroma3.it)

\section{Leonardo Sagnotti}

Istituto Nazionale di Geofisica e Vulcanologia, Via di Vigna Murata 605, IT-00143, Rome, Italy (leonardo.sagnotti@ingv.it)

\section{Domenico Cosentino}

Dipartimento di Scienze Geologiche, Università Roma Tre, Largo San Leonardo Murialdo 1, IT-00146 Rome, Italy

Also at Istituto di Geologia Ambientale e Geoingegneria, Area della Ricerca Roma 1 Montelibretti, Via Salaria Monterotondo Scalo, IT-00016 Rome, Italy (cosentin@uniroma3.it)

\section{Andrew P. Roberts \\ Research School of Earth Sciences, Australian National University, Canberra, ACT 0200, Australia (andrew.roberts@anu.edu.au)}

[1] We present paleomagnetic, rock magnetic and scanning electron microscope data from three upper Messinian stratigraphic sections from the Adana Basin (southern Turkey). The collected samples are from fine-grained units, which were deposited during the Messinian Salinity Crisis (within subchron C3r). Paleomagnetic results reveal an inconsistent polarity record, related to a mixture of magnetite and greigite that hinders determination of a reliable magnetostratigraphy. Three classes of samples are recognized on the basis of paleomagnetic results. The first is characterized by a single magnetization component, with normal polarity, that is stable up to $530-580^{\circ} \mathrm{C}$ and is carried by magnetite. The second is characterized by a single magnetization component, with reversed polarity, that is stable up to $330-420^{\circ} \mathrm{C}$. This magnetization is due to greigite, which developed after formation of slumps and before tectonic tilting of the studied successions. The third is characterized by reversed polarity, which is stable up to $530-580^{\circ} \mathrm{C}$. We interpret this component as a primary magnetization carried by fine-grained and magnetically stable detrital magnetite. Results indicate that in the Adana Basin the assumption that a primary magnetization is carried by magnetite, and a magnetic overprint carried by greigite, does not hold because a late magnetic overprint has also been found for 
magnetite-bearing samples. Our data illustrate the complexity of magnetostratigraphic reconstructions in successions characterized by variable mixtures of magnetic minerals with different magnetic stability that formed at different stages. We demonstrate the need to perform detailed magnetic mineralogy analyses when conducting magnetostratigraphic studies of clay-rich sediments from marine or lacustrine environments.

Components: 11,300 words, 11 figures.

Keywords: Messinian; remagnetization; reversals; rock and mineral magnetism; southern Turkey.

Index Terms: 1527 Geomagnetism and Paleomagnetism: Paleomagnetism applied to geologic processes; 1533 Geomagnetism and Paleomagnetism: Remagnetization; 1540 Geomagnetism and Paleomagnetism: Rock and mineral magnetism.

Received 22 May 2012; Revised 5 September 2012; Accepted 5 September 2012; Published 5 October 2012.

Lucifora, S., F. Cifelli, M. Mattei, L. Sagnotti, D. Cosentino, and A. P. Roberts (2012), Inconsistent magnetic polarities in magnetite- and greigite-bearing sediments: Understanding complex magnetizations in the late Messinian in the Adana Basin (southern Turkey), Geochem. Geophys. Geosyst., 13, Q10002, doi:10.1029/2012GC004248.

\section{Introduction}

[2] Greigite $\left(\mathrm{Fe}_{3} \mathrm{~S}_{4}\right)$ is an authigenic magnetic mineral that forms in sulfate-reducing environments as an intermediate phase in the process of pyrite formation [Berner, 1969, 1970, 1984; Canfield and Berner, 1987; Benning et al., 2000; Hunger and Benning, 2007]. Greigite can be preserved in sedimentary rocks if the supply of $\mathrm{H}_{2} \mathrm{~S}$ derived from organic carbon degradation is consumed in the presence of abundant reactive iron [Kao et al., 2004]. Greigite is important in paleomagnetic and environmental magnetic studies because it has been widely identified in marine and lake sediments, where it is often the main magnetic mineral [Roberts and Turner, 1993; Horng et al., 1998; Sagnotti and Winkler, 1999; Jiang et al., 2001; Roberts and Weaver, 2005; Rowan and Roberts, 2006; Larrasoaña et al., 2007; Vasiliev et al., 2007, 2008; Porreca et al., 2009; Roberts et al., 2011]. The reliability of paleomagnetic data from greigitebearing rocks is strongly debated because the timing of natural remanent magnetization (NRM) acquisition is often not well constrained. On one hand, magnetosomal greigite can survive over geological time scales and can record a primary NRM [Hüsing et al., 2007; Vasiliev et al., 2008]. Conversely, in many cases, greigite-bearing sediments have inconsistent polarity records and even contradictory polarities within the same stratigraphic horizon [Horng et al., 1998; Jiang et al., 2001], which suggests that authigenic greigite growth can occur with a significant delay with respect to deposition of the host sediments. Analyses of active marine depositional environments have demonstrated that greigite growth can continue for a long period after deposition [Liu et al., 2004; Rowan et al., 2009]. Ambiguity in understanding the timing of greigite nucleation in sediments has been often emphasized by comparing the remanence component carried by greigite with that carried by magnetite, which is often of primary origin. In several cases, sedimentary units that contain both magnetite and greigite as the main magnetic carriers have two coexisting magnetization components: a primary one, carried by detrital magnetite, and a secondary one related to late-diagenetic greigite growth [Florindo and Sagnotti, 1995; Horng et al., 1998; Sagnotti and Winkler, 1999; Sagnotti et al., 2005; Porreca et al., 2009; Porreca and Mattei, 2010, among many others]. Clear distinction between primary and secondary remanences carried by greigite is not, however, achievable in all cases and the genesis, relative ages, and interactions between magnetizations due to greigite and magnetite in sedimentary rocks are still debated.

[3] We present paleomagnetic, rock magnetic and scanning electron microscope (SEM) data from upper Messinian deposits of the Adana Basin (southern Turkey) (Figure 1). The Adana Basin is the onshore part of the Adana-Cilicia Basin [Aksu et al., 2005a], which developed mainly in Neogene time between the Cyprus Arc and the southern margin of the Central Anatolian Plateau (CAP). The post-Tortonian history of the Adana Basin is linked to uplift of the southern margin of the CAP [Cosentino et al., 2012; Schildgen et al., 2012a, 2012b] and to the paleoceanographic changes that affected the Mediterranean Basin during the Messinian salinity crisis (MSC) [Hsü et al., 1973; Krijgsman et al., 1999; CIESM, 2008, and references 
(a)

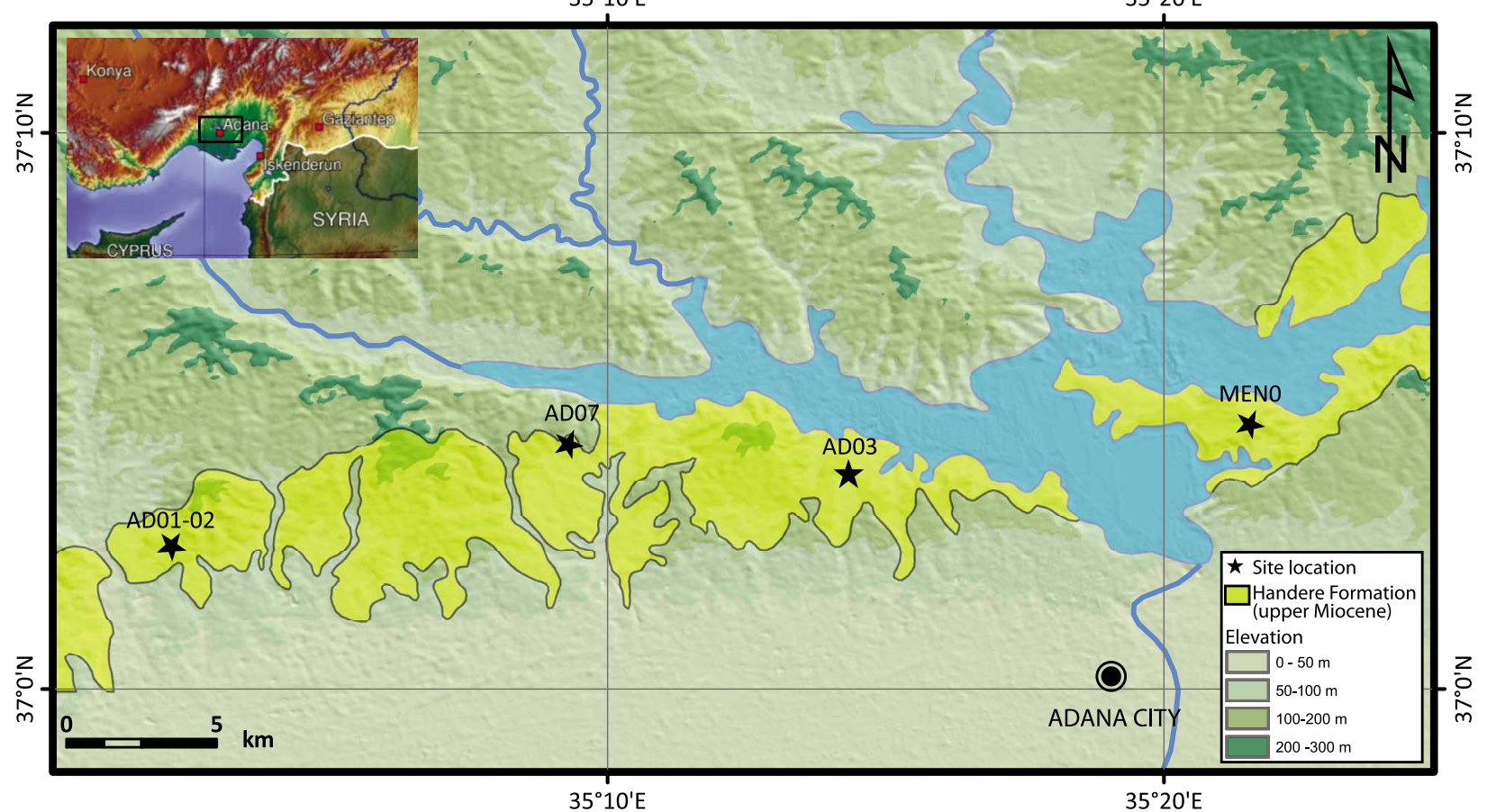

(b)

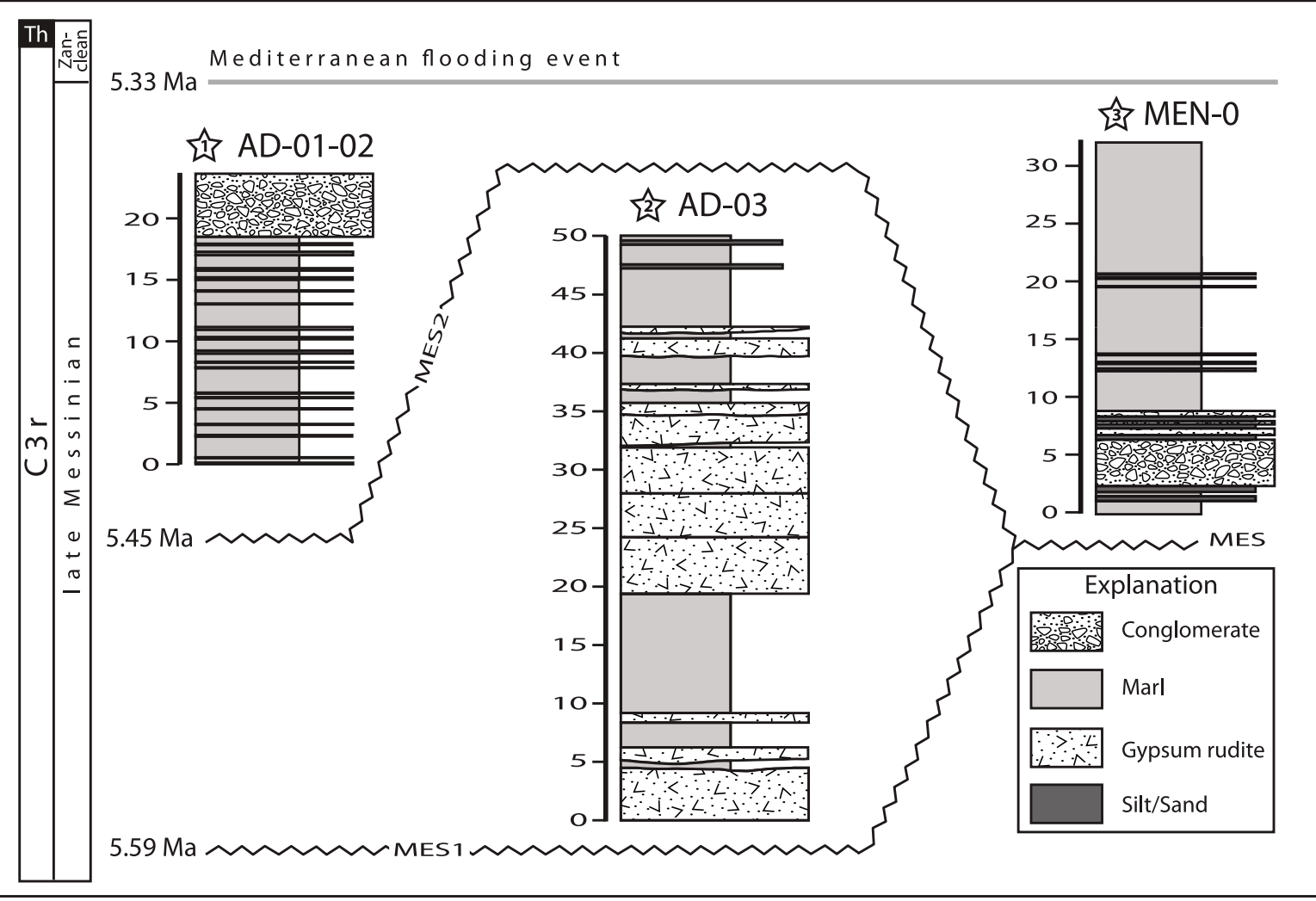

Figure 1. (a) Digital elevation model of the Adana Basin (location of the studied area is indicated in the inset). The distribution of Upper Miocene deposits (yellow) and the sampled localities (stars) are also shown on the map. (b) Stratigraphic correlation among the studied upper Messinian sections. Th: Thvera subchron. 
therein]. The Adana Basin represents the easternmost site in the Mediterranean where the MSC (5.96 Ma to $5.33 \mathrm{Ma}$ [Krijgsman et al., 1999]) was recorded. In the Adana Basin, the MSC deposits include the Lower Evaporites, the Messinian salt layer, the Upper Evaporites, and the Lago-Mare facies [Cosentino et al., 2010a, 2010b; Cipollari et al., 2012]. These Messinian units were all deposited within subchron $\mathrm{C} 3 \mathrm{r}$ of the geomagnetic polarity time scale, which has been calibrated by orbital tuning to $6.033-5.235 \mathrm{Ma}$ [Lourens et al., 2004]. Tectonic subsidence of the Adana Basin [Cosentino et al., 2010c], coupled with Messinian climate changes in the Mediterranean region [Griffin, 2002], induced high sedimentation rates during deposition of the late Lago-Mare facies (ca 5.45 to $5.33 \mathrm{Ma}$ ), which is characterized by a thick succession $(>1000 \mathrm{~m})$ of fluvial conglomerates with intercalated fine-grained deposits that lack fossils [Cosentino et al., 2010c; Cipollari et al., 2012]. In order to better constrain their age and depositional environment the latter fine-grained late Lago-Mare deposits were sampled and analyzed for paleomagnetic and rock magnetic studies. The sediments contain a complex magnetic mineralogy, with both primary magnetite and late diagenetic greigite. The presence of soft sediment deformation and of faultrelated deformation allows definition of the temporal relationships between tectono-sedimentary events and the magnetization recognized in the studied sections of the Adana Basin. This situation enables unraveling of complex magnetizations in greigitebearing sediments. Our work contributes to understanding such situations.

\section{Geological Setting and Stratigraphy of the Sampled Sites}

[4] According to Robertson [1998], the AdanaCilicia Basin developed in a region affected by extensional tectonics due to southward retreat of the subducting slab of the African plate. The sedimentary cover of the Adana Basin lies unconformably on basement rocks of the Central Taurides. From the Early Miocene, the Adana Basin has recorded transgressive-regressive cycles forced by regional tectonics and eustatic sea level changes. One of the major unconformities in the Adana Basin is of early Tortonian age (Late Miocene), with early Tortonian terrestrial red beds of the Kuzgun Formation resting unconformably on Serravallian outer shelf clays and marls of the Güvenç Formation [Ünlügenç, 1993]. A younger erosional surface that affects the Adana Basin (MES 1 , [Cosentino et al., 2010a, 2010b]) occurs within the MSC deposits, and corresponds to the Messinian Erosional Surface (MES) of the Mediterranean marginal basins [Cosentino et al., 2010a, 2010b; Cipollari et al., 2012, and references therein] (Figure 1b). The MES is related to the draw-down of Mediterranean Sea level, which occurred after deposition of the Lower Evaporites (ca 5.59 Ma) [Krijgsman et al., 1999] as a consequence of complete closure of the Gibraltar and other gateways [CIESM, 2008, and references therein]. At the evaporitic/post-evaporitic transition circulation of the Mediterranean waters was restricted, as suggested by higher authigenic uranium values in the early postevaporitic deposits compared with the sapropelitic layers of the Lower Evaporites [Sampalmieri et al., 2010]. Generally, the Messinian post-evaporitic deposits are characterized by clastic sediments, with intercalated fine-grained deposits that are rich in organic matter but almost barren of fossils. In the Adana Basin, clastic layered gypsum deposits with intercalated fine-grained sediments rich in organic matter cropout. They belong to the Resedimented Lower Evaporites of the MSC [Cosentino et al., 2010a, 2010b; Cipollari et al., 2012] and lie unconformably $\left(\mathrm{MES}_{1}\right)$ on the Lower Evaporites (Topçu section, close to the AD01 and AD02 sections studied here) or on the lower Messinian shallow marine deposits of the Kuzgun Formation.

[5] A younger Messinian erosional surface $\left(\mathrm{MES}_{2}\right)$ also affects the sedimentary succession of the Adana Basin, and separates the Lower Evaporite and Resedimented Lower Evaporite and pre-evaporitic marls (Kuzgun Formation) below, from an unconformably overlying continental unit (Handere Formation pro parte) that consists mainly of fluvial, coarse-grained deposits [Cosentino et al., 2010a, 2010b; Cipollari et al., 2012]. Some fine-grained intercalations of these mainly channelized fluvial deposits contain ostracods with Paratethyan affinities to the Messinian late Lago-Mare biofacies (Loxocorniculina djafarovi Zone) [Cosentino et al., 2010b; Cipollari et al., 2012]. In the Adana Basin, surface and subsurface data reveal the occurrence of the Zanclean flooding event [Cipollari et al., 2012], which defines the Messinian/Zanclean transition and the end of the MSC (5.332 Ma [Lourens et al., 1996, 2004]).

[6] In this study, we analyzed samples from the Messinian deposits that lie unconformably on $\mathrm{MES}_{1}$ or $\mathrm{MES}_{2}$ and are older than the Messinian/ Zanclean transition (Figure 1b), and thus they encompass the interval 5.59-5.33 Ma. The collected samples are from fine-grained deposits of both the Resedimented Lower Evaporites (AD03 section) and the channelized fluvial deposits of the Handere 
Formation (AD01, AD02, MEN0 sections and site AD07). The well constrained age of the analyzed samples implies that they were deposited during reversed polarity subchron C3r (6.033-5.235 Ma [Lourens et al., 2004]). In several places, especially close to the northwestern margin of the Adana Basin, Messinian deposits are affected by normal faults, with beds generally striking E-W with dips from $50^{\circ}$ to $85^{\circ}$. The Messinian units generally dip toward the SE throughout the Adana Basin.

\subsection{Sections From the Resedimented Lower Evaporites}

[7] Samples from the AD03 section $\left(37^{\circ} 03^{\prime} 48^{\prime \prime} \mathrm{N}\right.$; $\left.35^{\circ} 14^{\prime} 02^{\prime \prime} \mathrm{E}\right)$ were collected from a 50 -m-thick stratigraphic section about $8 \mathrm{~km} \mathrm{NW}$ of the city of Adana (Figures 1a and 1b). The sampled section lies just above the $\mathrm{MES}_{1}$ and is formed by massive resedimented gypsum beds (mainly gypsum rudites), interbedded with fine-grained deposits that contain ostracod assemblages, including Cyprideis sp. and Loxoconcha mülleri, from the Messinian early Lago-Mare biofacies (L. mülleri Zone) [Gliozzi et al., 2010; Grossi et al., 2011]). From the fine-grained intervals of the AD03 section (mainly clays and marly clays), 110 cores were drilled for paleomagnetic and rock magnetic analyses. The sampled beds have shallow dips with a bedding orientation at the base of the section of N092 (strike), $05^{\circ}$ (dip), whereas close to the top of the section it is $\mathrm{N} 087^{\circ}, 10^{\circ}$.

\subsection{Sections From the Channelized Fluvial Deposits of the Handere Formation}

[8] The Handere Formation, which lies unconformably above the youngest intraMessinian erosional surface $\left(\mathrm{MES}_{2}\right)$, was sampled at several stratigraphic sections (AD01, AD02, AD07, and MEN0), mainly from its lower part (Figures 1a and $1 \mathrm{~b})$. Sections AD01 (37 $\left.02^{\prime} 41^{\prime \prime} \mathrm{N} ; 35^{\circ} 02^{\prime} 15^{\prime \prime} \mathrm{E}\right)$ and AD02 $\left(37^{\circ} 02^{\prime} 33^{\prime \prime} \mathrm{N} ; 35^{\circ} 02^{\prime} 11^{\prime \prime} \mathrm{E}\right)$ were sampled close to the village of Topçu, about $25 \mathrm{~km}$ to the west of Adana city. The sampled sections are both from the basal fine-grained interval within the channelized fluvial conglomerates of the Handere Formation, and rest just above $\mathrm{MES}_{2}$ which crops out in the vicinity of the Topçu gypsum quarry. From this area, in a 20-m-thick composite section (AD01-02), we collected 93 samples. The bedding attitude at the base of the composite section is $\mathrm{N} 348^{\circ}$ (strike), $24^{\circ}$ (dip), whereas close to the top it is $\mathrm{N} 356^{\circ}, 10^{\circ}$. From one site (AD07) located between the AD03 section and the AD01-02 composite section $\left(37^{\circ} 04^{\prime} 23^{\prime \prime} \mathrm{N} ; 35^{\circ} 09^{\prime} 19^{\prime \prime} \mathrm{E}\right), 12$ cores were collected from a 2-m-thick layer of clays and marly clays interbedded with channelized fluvial conglomerates, just above $\mathrm{MES}_{2}$.

[9] The last stratigraphic section analyzed in this study was sampled along the Menekșe road, about $6 \mathrm{~km}$ to the NE of Adana city (MEN0 section, $37^{\circ} 04^{\prime} 43^{\prime \prime} \mathrm{N}, 35^{\circ} 09^{\prime} 19^{\prime \prime} \mathrm{E}$ ) (Figures $1 \mathrm{a}$ and $1 \mathrm{~b}$ ). It is a 30 -m-thick section that consists mainly of finegrained deposits that are affected by slumps in their lower part. The sampled section overlies channelized fluvial conglomerates of the Handere Formation. In total 81 samples were collected from the MEN0 section for paleomagnetic and rock magnetic analyses.

\section{Methods}

[10] Samples were collected using a gasoline-powered portable drill with a water-cooled diamond bit. The cores were oriented with a magnetic compass. Paleomagnetic and rock magnetic analyses were carried out at the paleomagnetic laboratories of Roma Tre University, the Istituto Nazionale di Geofisica e Vulcanologia (INGV, Rome, Italy), at the Alpine Laboratory of Paleomagnetism (ALP, Peveragno, Italy), at the Institute for Rock Magnetism (IRM, Minneapolis, USA) and at the Australian National University (ANU, Canberra, Australia).

[11] Anisotropy of magnetic susceptibility (AMS) was measured for all samples using a KLY-3S kappabridge magnetic susceptibility meter. Results are shown on an equal area stereographic projection using the Jelinek and Kropáček [1978] statistics. The NRM of standard cylindrical specimens was measured using a 2-G Enterprises superconducting rock magnetometer (SRM) equipped with DCSQUID coils within a magnetically shielded room. The NRM of one specimen per core was measured by means of progressive stepwise demagnetization using thermal or alternating field (AF) procedures. Thermal demagnetization was carried out using temperature increments $\left(80-100^{\circ} \mathrm{C}\right.$ up to $300^{\circ} \mathrm{C}$ and $30-50^{\circ} \mathrm{C}$ above $300^{\circ} \mathrm{C}$ ) until the NRM decreased to below the limit of instrument sensitivity or random changes appeared in the paleomagnetic directions. Stepwise AF demagnetization was carried out using a set of three orthogonal AF coils mounted in-line with the SRM system, with 5-10 mT increments up to $20 \mathrm{mT}$, followed by $20 \mathrm{mT}$ steps up to $100 \mathrm{mT}$.

[12] In order to identify the main magnetic minerals in the studied sediments, we carried out a series of rock magnetic analyses on selected specimens. The measurements included: (1) stepwise thermal 
(a)

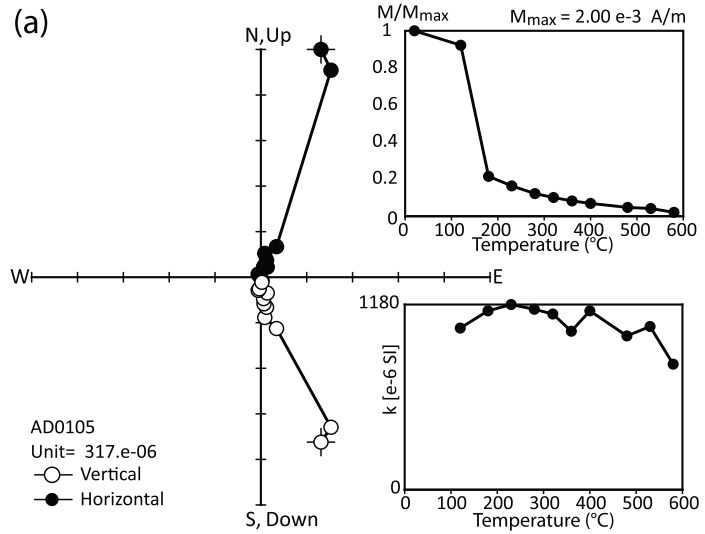

(c)

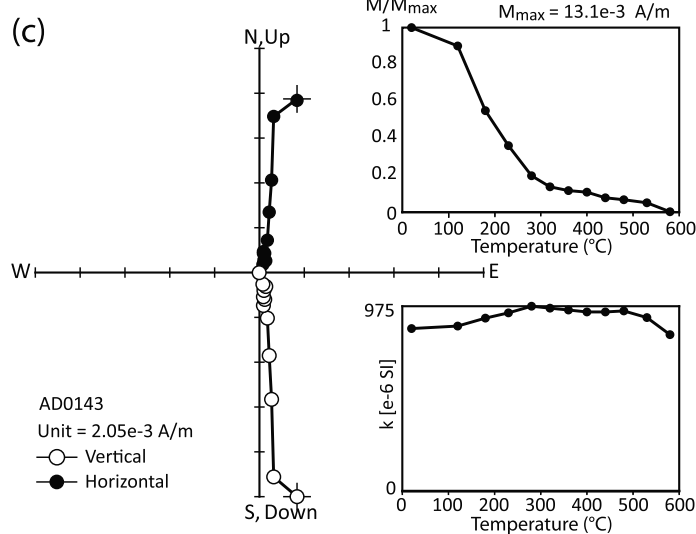

(e)
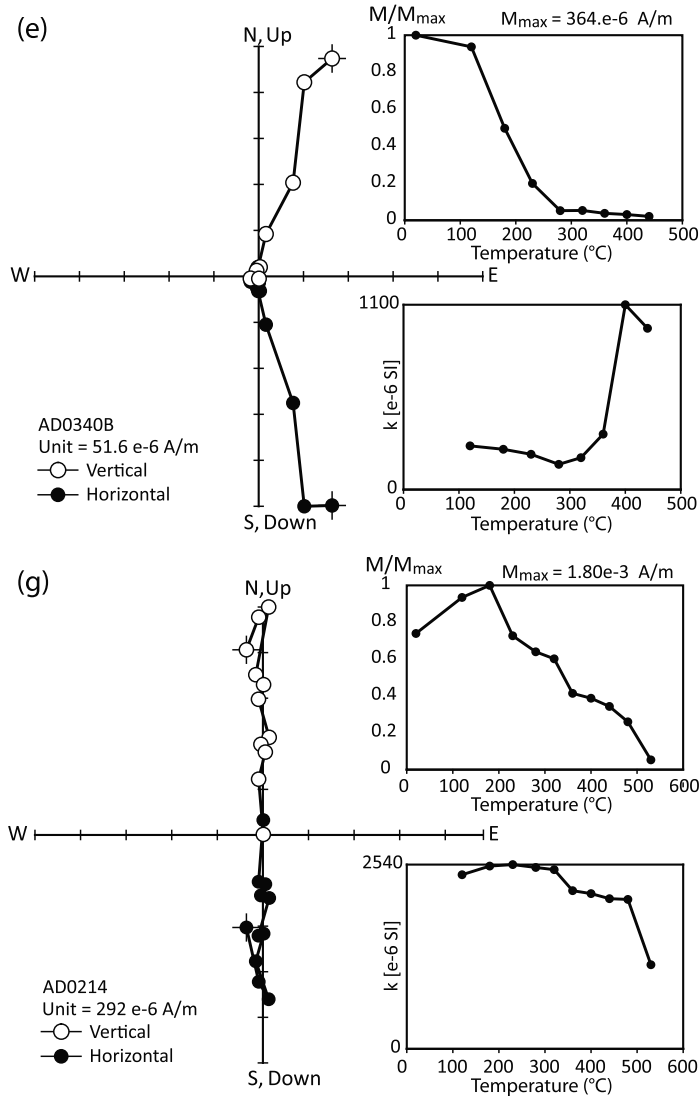
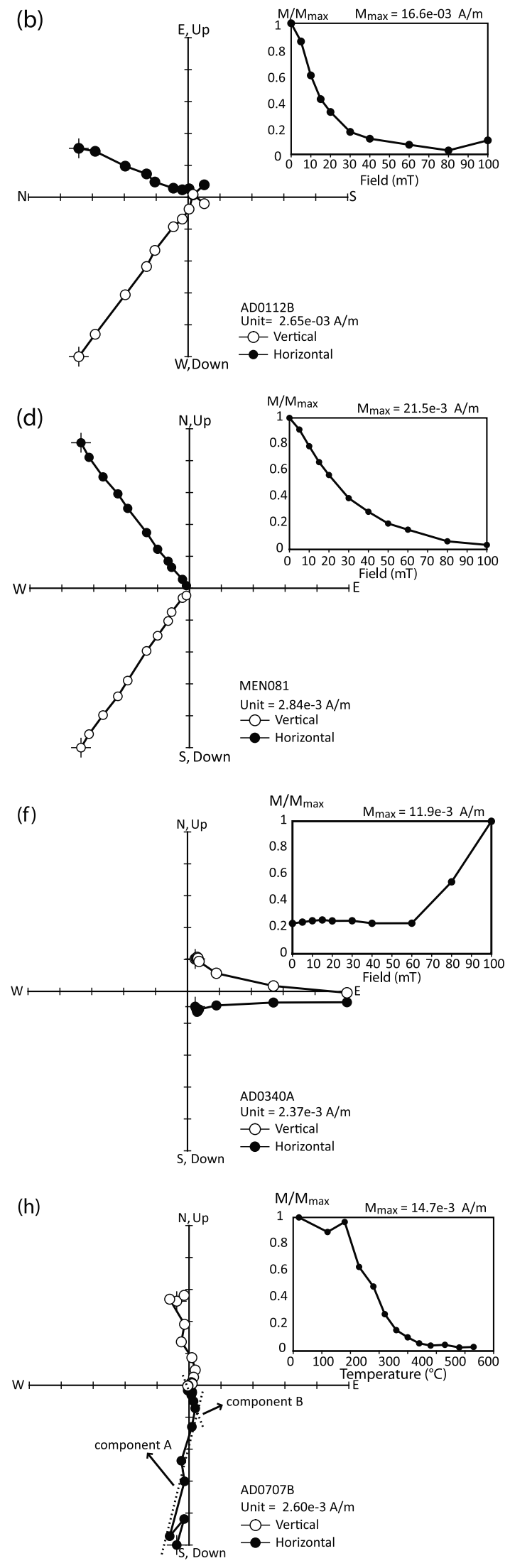

Figure 2 
demagnetization of a composite isothermal remanent magnetization (IRM) produced by sequential application of pulsed fields of $0.12 \mathrm{~T}, 0.4 \mathrm{~T}$ and $1.7 \mathrm{~T}$ along three mutually orthogonal sample axes for 14 samples distributed throughout the studied sections, and (2) hysteresis properties of small rock fragments from 46 distributed samples. The hysteresis properties were measured on a Micromag alternating gradient magnetometer (AGM model 2900, Princeton Measurements Corporation) with a maximum applied field of $1 \mathrm{~T}$. From hysteresis loops, after subtraction of the paramagnetic highfield susceptibility measured following magnetic saturation of the samples, we calculated the coercive force $\left(\mathrm{B}_{\mathrm{C}}\right)$, the saturation remanent magnetization $\left(\mathrm{M}_{\mathrm{RS}}\right)$ and the saturation magnetization $\left(\mathrm{M}_{\mathrm{S}}\right)$. Stepwise acquisition of an IRM and subsequent back-field DC demagnetization (both in a succession of fields up to $1 \mathrm{~T}$ ) were also measured on the same samples on the Micromag AGM. The coercivity of remanence $\left(\mathrm{B}_{\mathrm{CR}}\right)$ was computed from the back-field demagnetization curves. For 10 samples with high magnetic intensity we also analyzed firstorder reversal curves (FORC) [Pike et al., 1999; Roberts et al., 2000] and produced FORC diagrams using the UNIFORC Matlab code [Winklhofer and Zimanyi, 2006; Winklhofer et al., 2008].

[13] A field emission SEM (FESEM) (INCA Energy 450 EDXA system) Philips XL30 at the Center of Advanced Microscopy at the Australian National University (ANU) and a SEM (FEI SEM XL30) at the Interdepartmental Laboratory of Electron Microscopy at Roma Tre University, operated at $25 \mathrm{kV}$, were used for SEM observations. Elemental analyses were obtained, using an $\mathrm{X}$-Ray energy dispersive spectrometer (EDS), from point analyses of individual mineral grains.

\section{Results}

\subsection{Paleomagnetism}

[14] Some of the studied samples were too weakly magnetized (NRM values of about $1 \times 10^{-5} \mathrm{~A} / \mathrm{m}$ ) to allow reliable complete stepwise demagnetization, or gave unstable directions during stepwise demagnetization. Such samples were discarded from further analyses. The other samples have NRM intensities that range between $7 \times 10^{-5}$ and $2 \times$
$10^{-2} \mathrm{~A} / \mathrm{m}$, and demagnetization diagrams indicate stable paleomagnetic behavior with demagnetization vectors aligned along linear paths directed toward the origin of vector component diagrams, after removal of a viscous low coercivity remanence component at $5-10 \mathrm{mT}$ or $120-180^{\circ} \mathrm{C}$ (Figure 2). The characteristic remanent magnetization (ChRM) was determined by principal component analysis [Kirschvink, 1980] for 178 specimens, where the maximum angular deviation (MAD) was less than $15^{\circ}$. The ChRM, however, has variable polarity and stability, which suggests the presence of a complex magnetic mineralogy in the analyzed sequences.

[15] A first class of samples is characterized by a single magnetization component, with normal polarity (Figures 2a-2d). These samples undergo a sharp decrease of NRM intensity between $180^{\circ} \mathrm{C}$ and $320^{\circ} \mathrm{C}$ and are completely demagnetized at $580^{\circ} \mathrm{C}$ (Figures $2 \mathrm{a}$ and $2 \mathrm{c}$ ). The high-temperature component is stable between $320^{\circ}$ and $580^{\circ} \mathrm{C}$ and represents $10-20 \%$ of the NRM. No significant change in magnetic susceptibility was observed during heating. When AF treatment is used, data for these samples decay linearly toward the origin up to $60-80 \mathrm{mT}$ and do not evidently acquire any gyromagnetic remanent magnetization (GRM) (Figures $2 \mathrm{~b}$ and $2 \mathrm{~d}$ ).

[16] A second class of samples is characterized by a single magnetization component with reversed polarity. The ChRM directions were computed by fitting a linear component between 120 and $180^{\circ} \mathrm{C}$ and $330-420^{\circ} \mathrm{C}$ for the thermally demagnetized samples (Figure 2e), and between 5 and $10 \mathrm{mT}$ and 50-60 mT for samples treated with AF demagnetization (Figure 2f). The magnetic susceptibility of these samples increased sharply during heating at around $330-360^{\circ} \mathrm{C}$. AF-demagnetized samples are characterized by acquisition of a spurious GRM above 50-60 $\mathrm{mT}$, which results in a dramatic increase in remanent magnetization intensity with ongoing AF treatment (Figure 2f).

[17] A third type of behavior was observed in a few samples. After removal of a viscous low temperature normal polarity component at $120-180^{\circ} \mathrm{C}$, the demagnetization diagrams indicate stable paleomagnetic behavior with demagnetization vectors aligned along linear paths oriented toward the origin of the diagrams, with reversed polarity (Figure 2g). The ChRM directions were computed

Figure 2. Representative vector component diagrams of demagnetization data (in tilt-corrected coordinates). For each sample, (a, c, e, g, h) progressive thermal or (b, d, f) AF demagnetization data (step values are in degrees Celsius or $\mathrm{mT}$, respectively) are reported. Bulk susceptibility values measured after each thermal demagnetization step are also shown (see text for further details). 


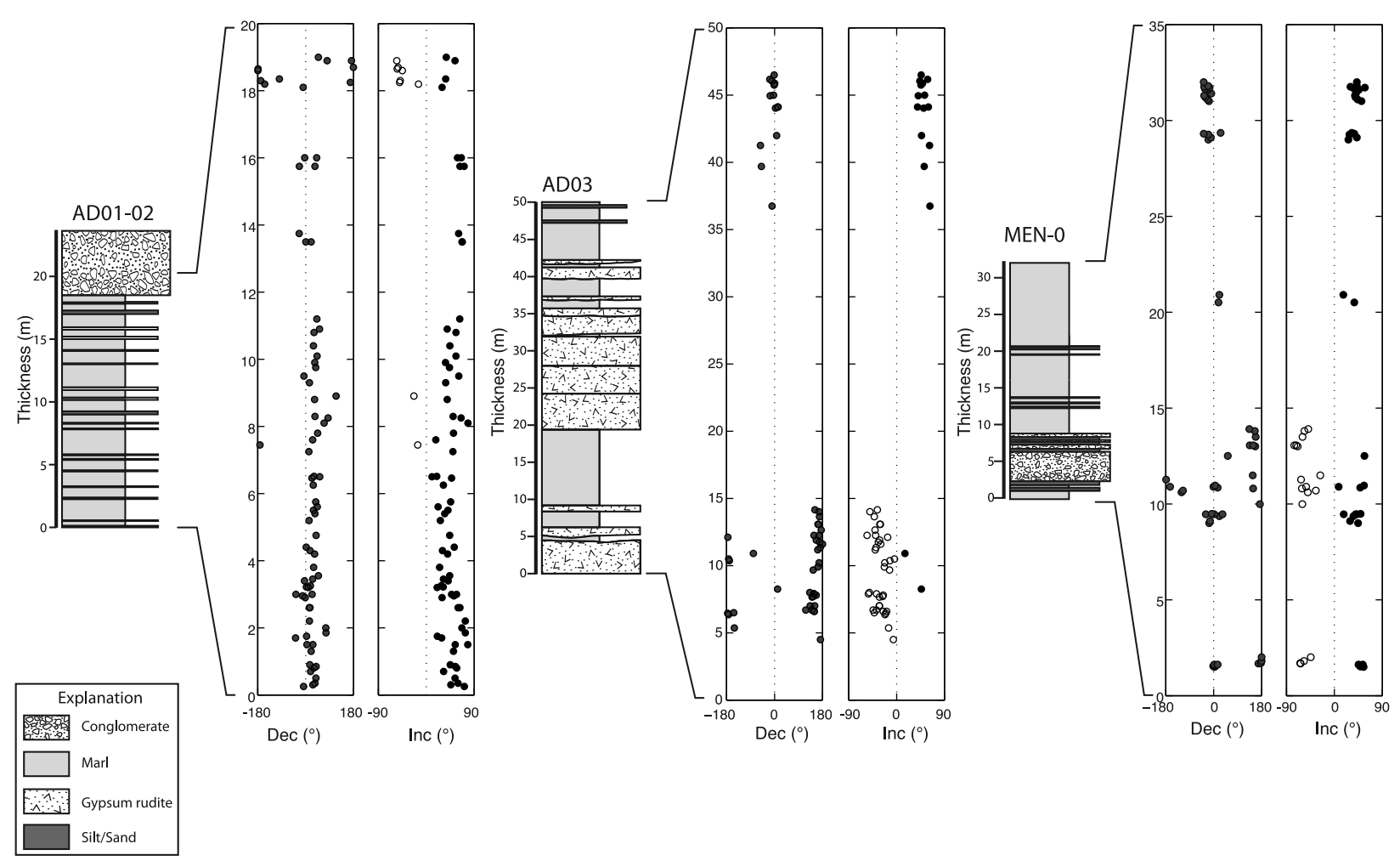

Figure 3. Stratigraphic summary of ChRM declination and inclination data for the analyzed samples from the AD01-02, AD03 and MEN0 sections.

by fitting a linear component between 180 and $230^{\circ} \mathrm{C}$ and $530-580^{\circ}$. No significant magnetic susceptibility increase was observed during heating for these samples.

[18] Finally, in some rare cases two distinct magnetization components with reversed polarity were recognized, which suggests the coexistence of two distinct mineralogical phases (Figure 2h). For these samples we recognized a low temperature magnetic component, which can be isolated between 180 and $230^{\circ}$ and $360-390^{\circ} \mathrm{C}$, and a high temperature component, isolated between 360 and $390^{\circ} \mathrm{C}$ and $530-580^{\circ} \mathrm{C}$.

[19] The ChRM directions for samples from the Adana Basin indicate that the sampled sections are characterized by both normal and reversed ChRM polarities $(38 \%$ of samples have reversed polarity and $62 \%$ have normal polarity). All samples from AD07 have reversed polarity. The stratigraphic distribution of paleomagnetic results along the AD01-02, AD03 and MEN0 sections is shown in Figure 3. All sections record both normal and reversed polarities; in particular the AD01-02 and MEN0 sections do not have a clearly defined stratigraphic distribution of magnetic polarities. In some cases, demagnetization results produced inconsistent polarities within the same core. The AD03 section is characterized generally by reversed polarity in the lower part and by normal polarity in the upper part.

[20] ChRM directions are shown for all samples on equal area projections in Figure 4 before and after tilt correction, together with mean paleomagnetic directions calculated separately for normal and reversed polarity samples, computed using Fisher [1953] statistics. In geographic coordinates, the mean paleomagnetic direction for normal polarity components is Dec. $=356.1^{\circ}$, Inc. $=53.4^{\circ}$, with $\alpha_{95}=3.3^{\circ}$ (Figure 4a). This direction is almost coincident with that of the expected geocentric axial dipole (GAD) field for the study area $\left(\right.$ Dec. $=0$, Inc. $\left.=56.5^{\circ}\right)$. When the tectonic tilt correction is applied, the mean direction becomes Dec. $=11.3^{\circ}$; Inc. $=49.5^{\circ}$, with $\alpha_{95}=3.9^{\circ}$ (Figure 4a), which is statistically distinct from the present-day GAD reference direction. The mean paleomagnetic direction for reversed polarity components is Dec. $=163.2^{\circ}$, Inc. $=-37.2^{\circ}$, with $\alpha_{95}=5.0^{\circ}$ in geographic coordinates (Figure 4a), which becomes Dec. $=166.2^{\circ}$, Inc.$=-41.4^{\circ}$, with $\alpha_{95}=4.8^{\circ}$, when the tectonic tilt correction is applied (Figure 4a). In order to verify the relative 
(a)
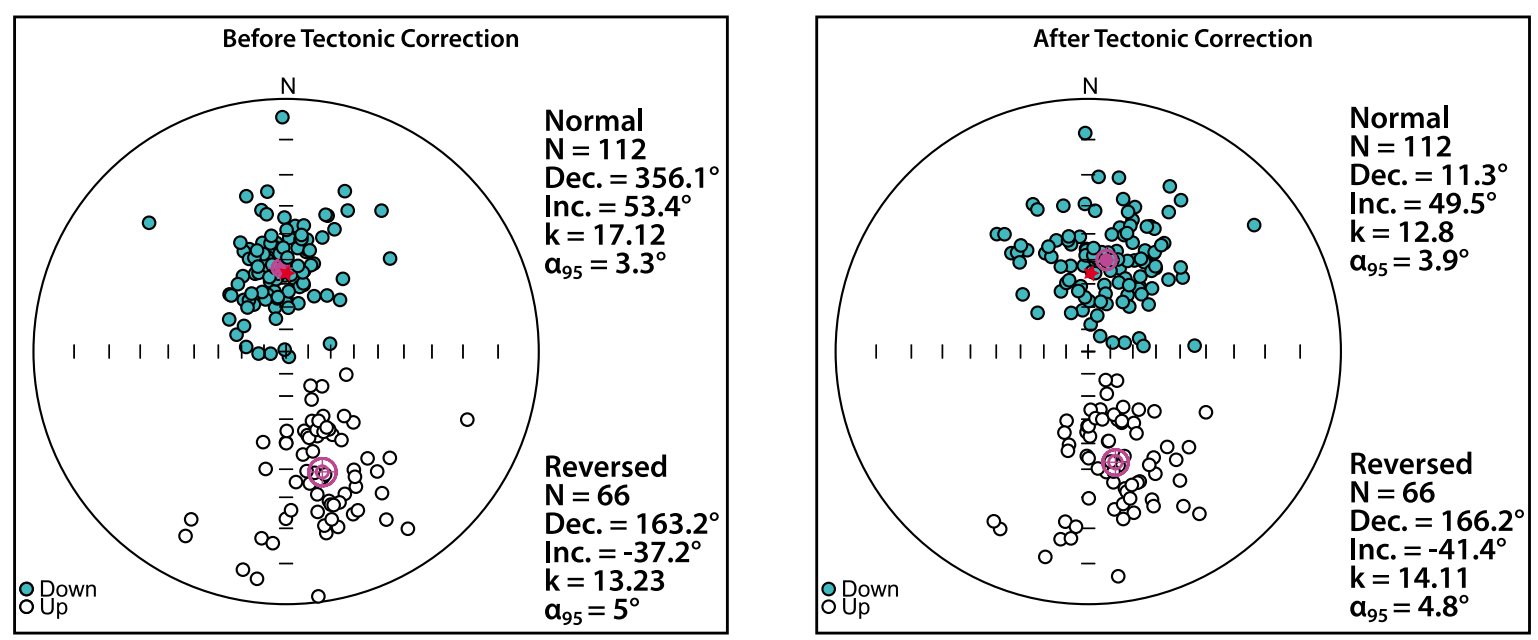

REVERSAL TEST

(b)
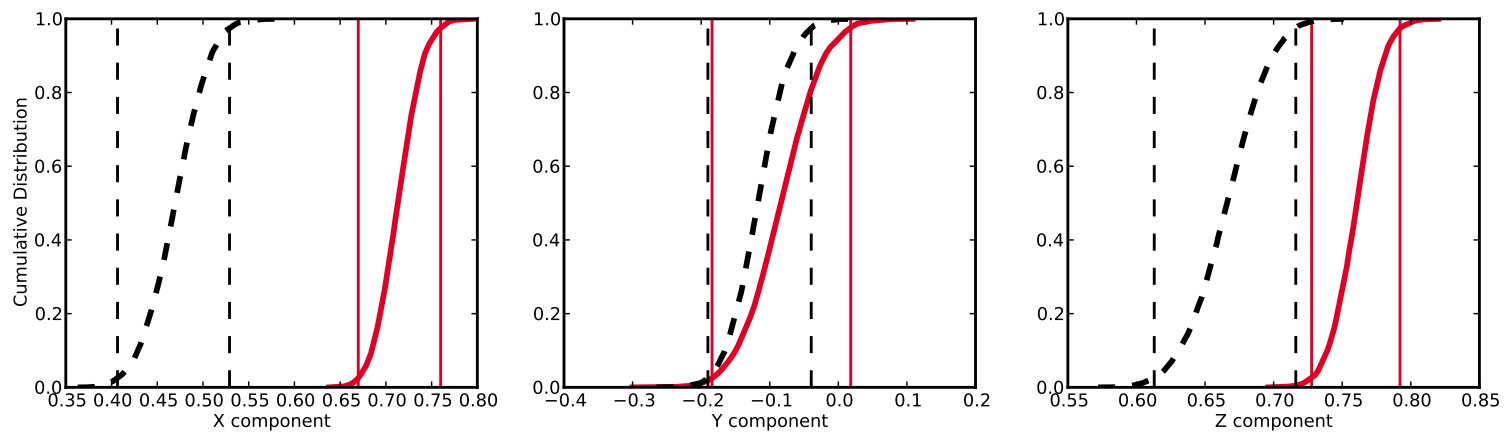

\section{FOLD TEST}

Normal Polarity Samples

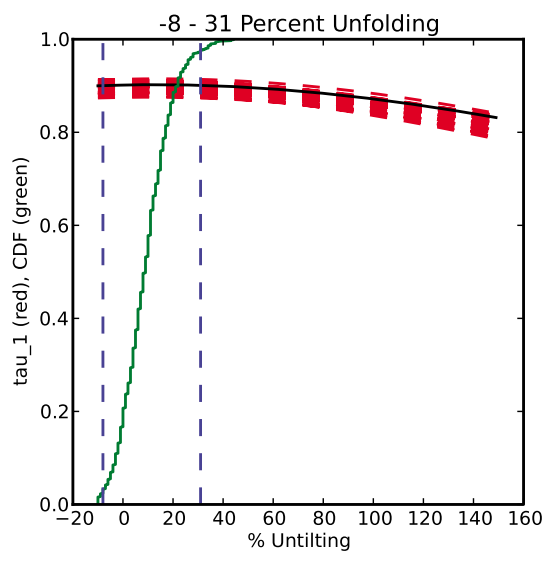

Reversed Polarity Samples

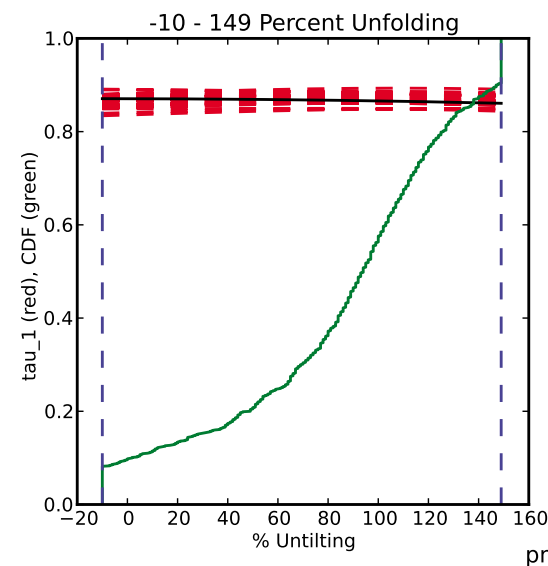

pmagpy-2.93

Figure 4. (a) Equal-area stereographic projections of ChRM directions for samples from the Adana Basin. Green and white circles represent projections onto the lower and upper hemisphere, respectively. The violet symbols represent the normal (and reversed) polarity mean paleomagnetic directions, with associated $95 \%$ confidence limits. Stars indicate the geocentric axial dipole (GAD) field direction for the study area $\left(\right.$ Dec. $=0^{\circ}$, Inc. $=56^{\circ}$ ). Data are plotted (left) before and (right) after tectonic tilt-correction. (b) Reversal test for the analyzed samples. (c) Fold test for (left) normal and (right) reversed polarity samples. Red dashed lines represent the trends of the largest eigenvalues $\left(\tau_{1 \mathrm{~s}}\right)$ of the orientation matrices from representative pseudo-samples drawn from Figure $4 \mathrm{a}$ as they evolve during untilting. The directions are adjusted for tilt incrementally from $-10 \%$ to $150 \%$. The green line is a cumulative distribution plot of maxima in $\tau_{1}$ from 500 pseudo-samples. These are sorted and the $95 \%$ confidence interval (blue dashed lines) for the degree of unfolding required to produce the tightest grouping (the highest $\tau_{1}$ ) is thus constrained to lie between -8 and $31 \%$ for the normal polarity samples and between -10 and $149 \%$ for the reversed polarity samples. 
timing of acquisition of the normal and reversed polarity components, we applied both reversal and fold tests to the whole set of ChRM data, following the procedure reported by Tauxe et al. [1991].

[21] Results of the reversal test are reported in Figure $4 \mathrm{~b}$, where it is shown that the $95 \%$ confidence bounds for the normal and reversed polarity populations only overlap each other for the $y$ component, whereas the $95 \%$ confidence bounds for the $\mathrm{z}$ and $\mathrm{x}$ components do not. This indicates that the mean paleomagnetic directions for samples with normal and reversed polarity are not antipodal. Therefore, the reversal test is negative. Samples with normal and reversed polarities either acquired their magnetizations at different times or one of the two data populations is affected by some later magnetic overprint that was not removed during stepwise demagnetization. On the basis of these data, we decided to handle the normal and reversed polarity samples separately. The fold test on normal polarity samples is negative because the eigenvalues $\tau_{1}$ of the orientation matrix $\mathrm{T}$ are highest at $0 \%$ unfolding with the calculated $95 \%$ confidence interval spanning $-8 \%$ and $31 \%$ unfolding, which suggests that the ChRM was likely acquired after tectonic tilting (Figure 4c). The fold test for the reversed polarity samples is not statistically significant (Figure 4c) because there is not a large variation in bedding orientation along the sampled sections and no variability of the eigenvalues $\tau_{1}$ of the orientation matrix $\mathrm{T}$ (the calculated $95 \%$ confidence interval is between $-10 \%$ and $149 \%$ unfolding). However, mean ChRM directions are slightly better grouped after tectonic correction than before tectonic correction (Figure 4a), which suggests that the magnetization was acquired before tilting of the beds.

[22] In the MEN0 section, among the 52 isolated ChRM directions, 8 are for samples from two different layers, which were folded by synsedimentary slumps. The presence of slump structures, which range from smoothly curving to isoclinal folds, suggests different degrees of consolidation and stiffness of sediments. This is important because more consolidated sediments could have magnetic particles already locked-in, whereas soft-sediment slumping could be more favorable to fixing of a magnetic remanence after slumping.

[23] A 10-cm-thick carbonate-rich layer, which forms an isoclinal, recumbent fold, which extends for several meters, forms the first studied slump. In this level ChRM directions were computed for six samples by fitting a linear component to the demagnetization data between 120 and $180^{\circ} \mathrm{C}$ and $330-440^{\circ} \mathrm{C}$. This normal polarity component has a mean direction Dec. $=12.3^{\circ}$, Inc. $=38.3^{\circ}(\mathrm{k}=15.6$, $\alpha_{95}=17.5^{\circ}$ ) in geographic coordinates. After slump unfolding, the ChRM direction for 2 samples becomes oriented toward the north with an upward inclination, and the paleomagnetic directions for the slump become much more scattered (mean tilt corrected direction: Dec. $=357.8^{\circ}$, Inc. $=7.9^{\circ}$, $\mathrm{k}=2.02, \alpha_{95}=65^{\circ}$ ) (Figure 5a). The second studied slump consists of clay and marly layers, which form a meter-scale recumbent fold with a gently rounded hinge. In this slump we obtained only two ChRM directions, with reversed polarity. The ChRM directions were computed by fitting a linear component between $120^{\circ}$ and $300^{\circ} \mathrm{C}$. The two directions are well grouped in geographic coordinates, whereas they are more dispersed when the slumped beds are restored to the pre-folding attitude (Figure 5b). These data suggest that, in the slumped layers, both normal and reversed polarity samples acquired their magnetization after slump formation.

\subsection{Rock Magnetism}

[24] Magnetic susceptibility ( $\kappa$ ) is highly variable within the sampled sections, with most samples characterized by susceptibility values in the 200 $400 \times 10^{-6}$ SI range (Figure 6a). These values are typical of fine-grained sediments with low ferrimagnetic mineral content, whose susceptibility and magnetic fabric are mostly determined by paramagnetic phyllosilicates in the clay matrix [Borradaile et al., 1986; Rochette, 1987; Sagnotti et al., 1998]. Some samples, however, have much higher susceptibility values (up to $6000 \times 10^{-6} \mathrm{SI}$ ), which suggest a larger ferrimagnetic mineral content, which determines the magnetic fabric and overwhelms the paramagnetic contribution [Cifelli et al., 2009]. AMS data indicate that a normal magnetic fabric characterizes the Adana Basin sections, with minimum susceptibility axes sub-vertical and perpendicular to the bedding plane. The distribution of maximum susceptibility axes indicates dispersion of the magnetic lineations in the bedding plane, with maximum clustering around a NNESSW orientation (Figure 6b). The degree of anisotropy $\mathrm{P}^{\prime}$ is generally less than 1.15 and the shape parameters for individual AMS ellipsoids are typical of weakly deformed sediments, with most samples having an oblate susceptibility ellipsoid $(\mathrm{T}>$ 0) (Figure 6b). A few samples are, however, 


\section{Before Tectonic Tilt Correction After Tectonic Tilt Correction}

(a)
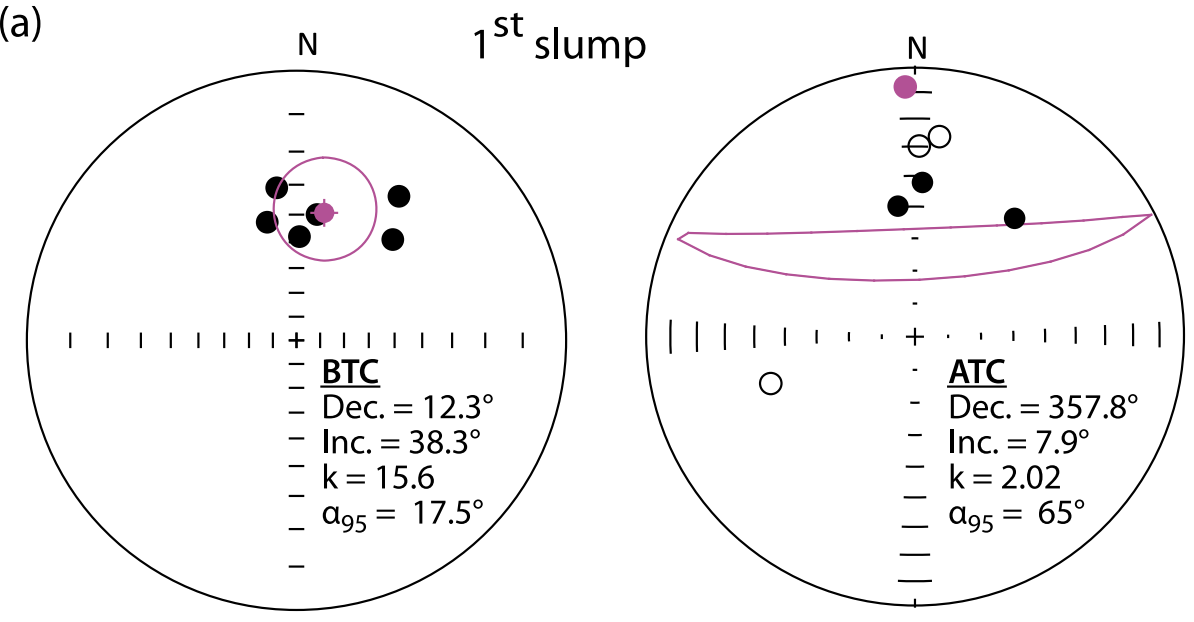

(b)
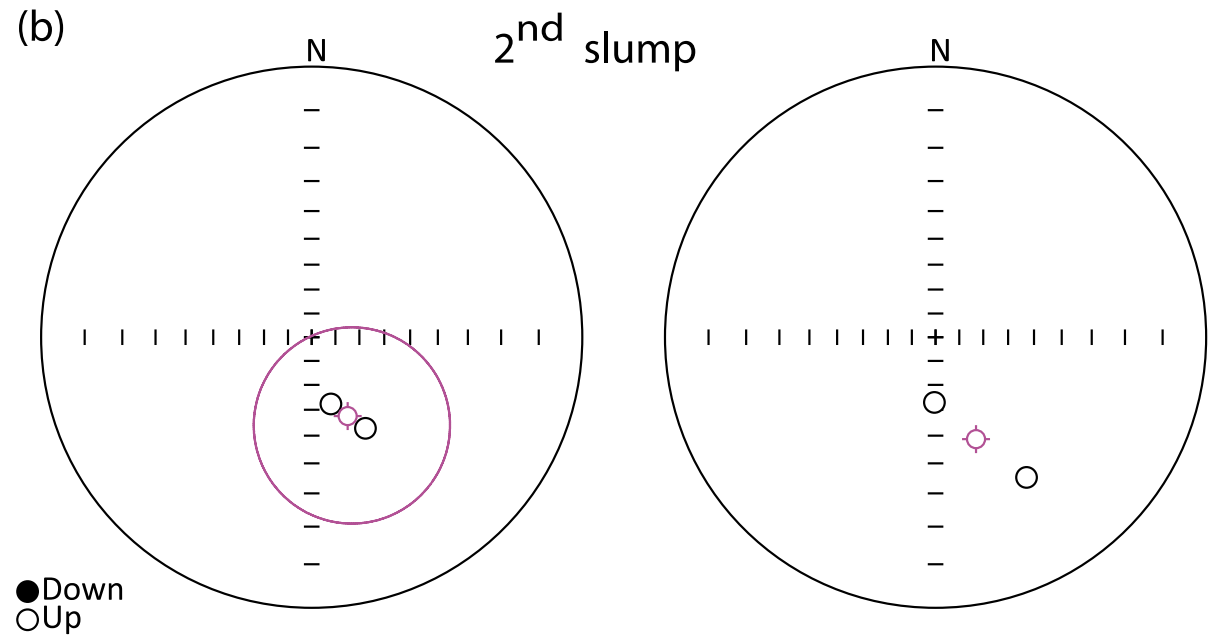

Figure 5. Equal-area stereographic projection of ChRM directions for samples collected from two different slumps within the MEN0 section. Purple circles and lines are the mean paleomagnetic directions and associated confidence circles.

characterized by triaxial or even moderately prolate AMS ellipsoids (Figure 6c).

[25] Thermal demagnetization of a composite IRM [Lowrie, 1990] indicates that most of the remanence is carried by low- and intermediate-coercivity minerals. The intermediate-coercivity magnetic phase is prevalent in some samples and has a maximum unblocking temperature of around $300-400^{\circ} \mathrm{C}$ (Figure 6d). For some samples, a low-coercivity fraction remains above $400^{\circ} \mathrm{C}$, which completely disappears at $600^{\circ} \mathrm{C}$ (Figure 6e). In other samples, most of the IRM is held by the low-coercivity component and is gradually removed by thermal demagnetization, with maximum unblocking temperatures of around $580^{\circ} \mathrm{C}$ (Figure 6f).

[26] Hysteresis loops reveal two main types of magnetic behavior, which suggest the presence of two magnetic minerals. The first type of loop has a more open shape (Figures 7a and 7b) and the second has a thin, almost completely closed shape (Figures $7 \mathrm{c}$ and $7 \mathrm{~d}$ ). $\mathrm{B}_{\mathrm{C}}$ values define two main groups: one is characterized by low coercivities $\left(B_{C}=10-20 \mathrm{mT}\right)$, while the other has higher coercitivities $\left(\mathrm{B}_{\mathrm{C}}=30-35 \mathrm{mT}\right)$. Data are scattered on a $\mathrm{M}_{\mathrm{RS}} / \mathrm{M}_{\mathrm{S}}$ versus $\mathrm{B}_{\mathrm{CR}} / \mathrm{B}_{\mathrm{C}}$ plot [Day et al., 1977], with $\mathrm{M}_{\mathrm{RS}} / \mathrm{M}_{\mathrm{S}}$ values between 0.10 and 0.31 and $B_{C R} / B_{C}$ values between 1.5 and 3.5. IRM acquisition curves have two different behaviors: for some samples, IRM is saturated in fields of ca $0.3 \mathrm{~T}$, whereas for other samples saturation is reached at higher fields (ca $0.7 \mathrm{~T}$ ), which suggests that two magnetic minerals with distinct coercivities are present in the sediments (Figure 7e). When plotted in a Day plot (Figure 7f), hysteresis parameters define a main cluster within the central area which, 
(a)

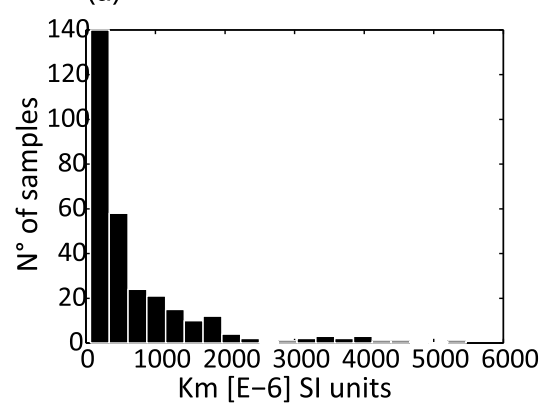

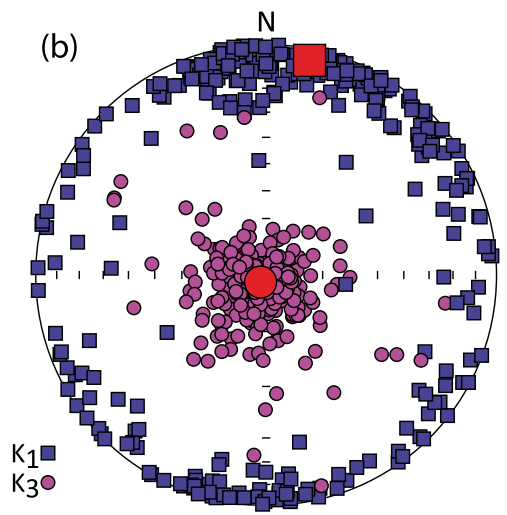

(c)

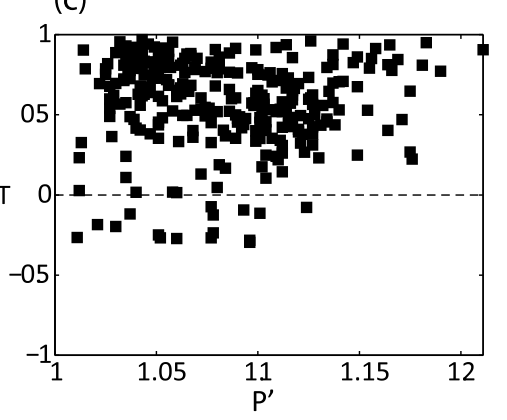

(d)

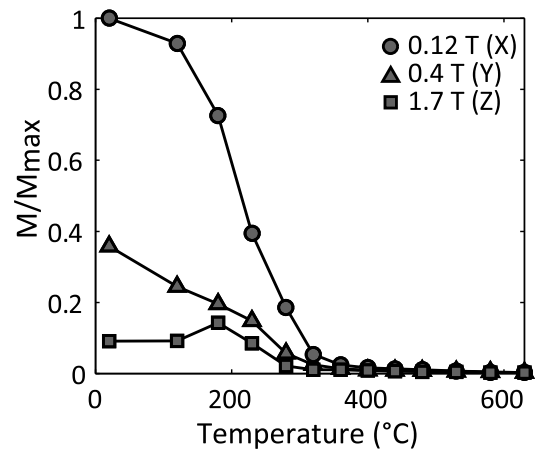

(e)

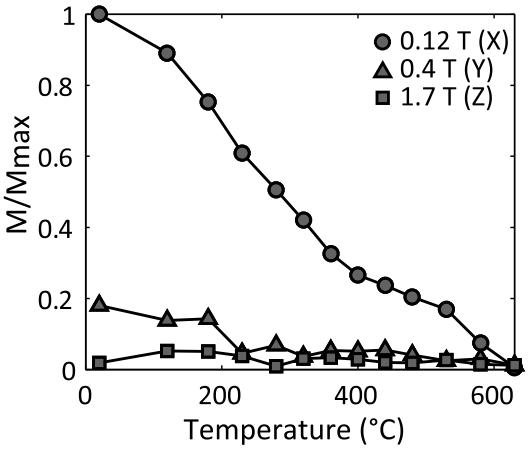

(f)

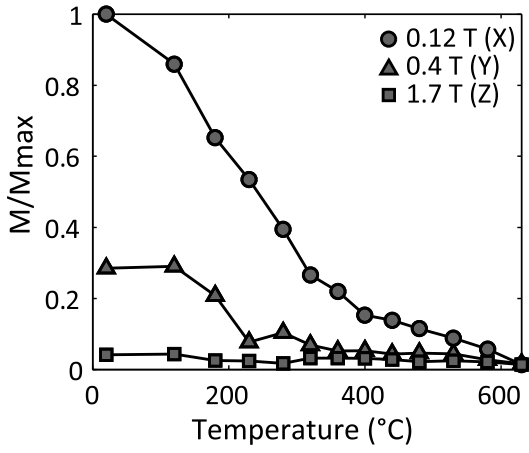

Figure 6. (top) AMS results from the Adana Basin. (a) Frequency distribution of susceptibility $\left(\mathrm{K}_{\mathrm{m}}\right)$ values. (b) AMS ellipsoids for individual samples plotted on an equal-area, lower hemisphere stereographic projection (red square and circle represent the site mean $\mathrm{K}_{1}$ and $\mathrm{K}_{3}$, respectively). (c) Degree of corrected anisotropy $\mathrm{P}^{\prime}$ versus shape factor $\mathrm{T}$ $\left(\mathrm{T}=\left(2\left(\eta_{2}-\eta_{3}\right) /\left(\eta_{1}-\eta_{3}\right)-1 ; \mathrm{P}^{\prime}=\exp \left\{2\left[\left(\eta_{1}-\eta\right)^{2}+\left(\eta_{2}-\eta\right)^{2}+\left(\eta_{3}-\eta\right)^{2}\right]\right\}^{1 / 2}\right)\right.$, as defined by Jelinek [1981]. (bottom) Thermal demagnetization of a composite 3-axis IRM produced sequentially in fields of 1.7, 0.4 and $0.12 \mathrm{~T}$ for representative samples (following Lowrie [1990]). Most of the IRM is carried by soft- and intermediate-coercivity components ( $\mathrm{X}$ and $\mathrm{Y}$ axes), which can be identified as (d) greigite (i.e., chemical decomposition temperature of $280-350^{\circ} \mathrm{C}$ ), (e) magnetite (i.e., unblocking temperature around $580^{\circ} \mathrm{C}$ ); and (f) magnetite and greigite mixtures.

for pure magnetite, defines the field for 'PSD' grains or for mixtures of $\mathrm{SD}$ and $\mathrm{MD}$ grains [Dunlop, 2002]. A few data define a trend toward the area typical for SD particles. Even if mixed magnetic assemblage occurs, these data suggest different proportions of mixing between magnetic particles with distinct compositions and grain sizes (domain state).

[27] FORC diagrams confirm the presence of two mineral phases. The first (Figure 8a) is characterized by concentric contours around a central peak, with $\mathrm{B}_{\mathrm{C}}$ values around $65 \mathrm{mT}$ and a negative region in the lower left-hand part of the FORC diagram. The negative region in the lower left-hand part of the diagram is typical of SD particle assemblages [cf. Newell, 2005], while the $\mathrm{B}_{\mathrm{C}}$ value at the peak of the distribution $(60-70 \mathrm{mT})$ indicate that the magnetic mineral is greigite $\left(\mathrm{Fe}_{3} \mathrm{~S}_{4}\right)$ [Roberts, 1995; Sagnotti and Winkler, 1999; Roberts et al., 2006, 2011]. Concentric contour lines around a central peak characterize the second magnetic phase (Figures $8 \mathrm{~b}$ and $8 \mathrm{c}$ ), with $\mathrm{B}_{\mathrm{C}}$ values of around 10 $20 \mathrm{mT}$, and an asymmetric FORC distribution around the $\mathrm{B}_{\mathrm{U}}=0$ line. This behavior is typical of PSD magnetite grains [Roberts et al., 2000; Pike et al., 2001a, 2001b; Muxworthy and Dunlop, 2002], although the negative region in the lower left-hand part of the diagrams in Figures $8 \mathrm{~b}$ and $8 \mathrm{c}$ suggests a contribution from a SD-like magnetization. 

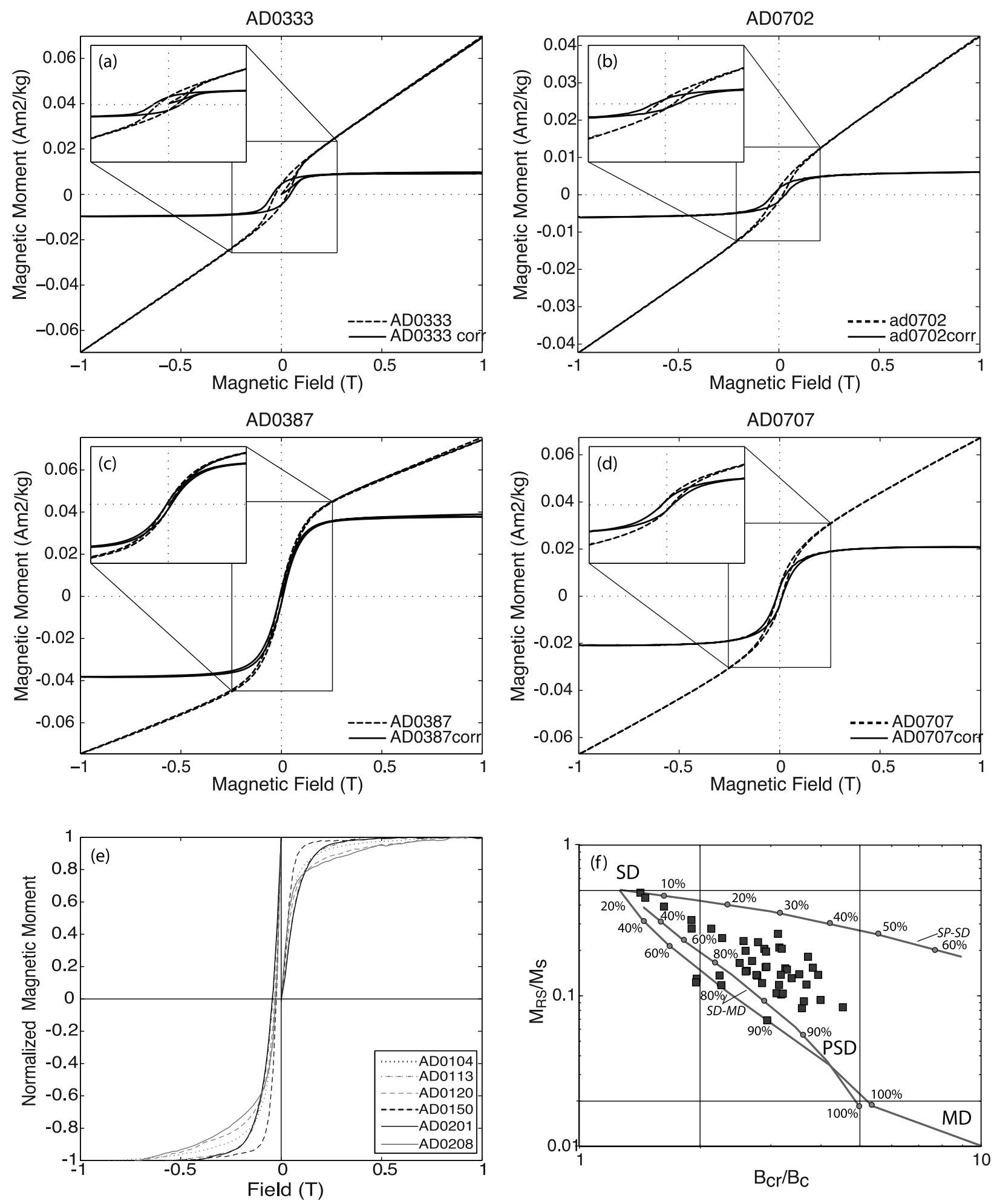

Figure 7. (a-d) Hysteresis loops for representative samples from the Adana Basin. There is a strong paramagnetic contribution from the clay matrix (dashed lines). Hysteresis is more visible after subtraction of the paramagnetic contribution and magnification close to the origin. The loops are typical of fine ferrimagnetic grains (SD and PSD). (e) Stepwise acquisition of an isothermal remanent magnetization (IRM) in fields up to $1 \mathrm{~T}$ and back-field demagnetization curves for representative samples. (f) Hysteresis ratios $\left(B_{C R} / B_{C}\right.$ versus $M_{R S} / M_{S}$ ) from representative samples plotted on a log-log scale [after Day et al., 1977]. The diagram includes theoretical mixing lines for mixtures of single domain (SD) and multidomain (MD) magnetite grains [after Dunlop, 2002]. 

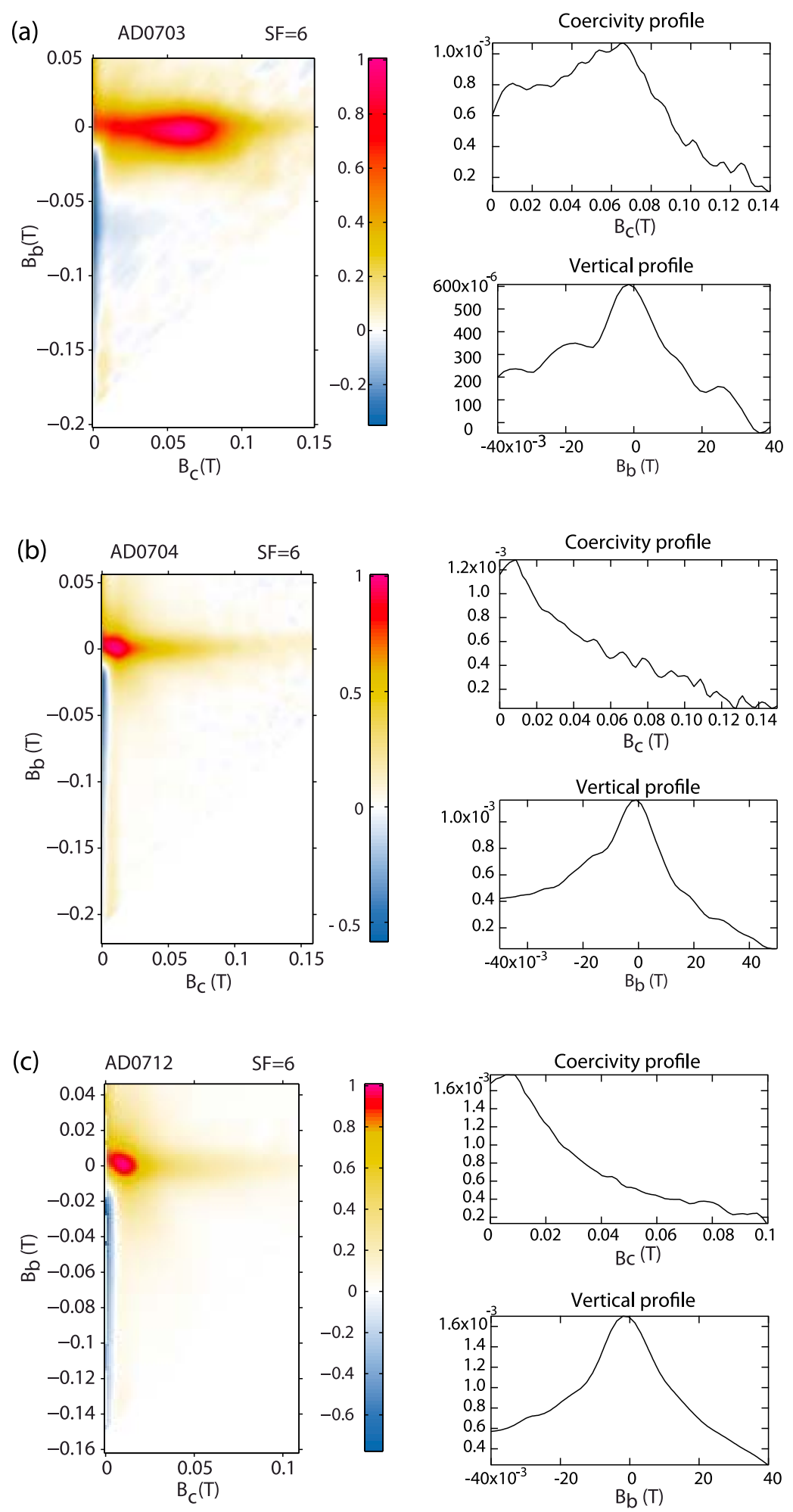

Figure 8. FORC diagrams for representative samples. (left) Representative FORC diagrams processed with the code of Winklhofer and Zimanyi [2006] and Winklhofer et al. [2008]. (right) Vertical $\left(\mathrm{B}_{\mathrm{u}}=0\right)$ and horizontal $\left(\mathrm{B}_{\mathrm{b}}=0\right)$ profiles through the peak of the respective FORC distribution. (a) Diagrams characterized by closed concentric contours about a central peak and a distinctive negative region, which is typical of SD grains (greigite). (b and c) Diagrams with an asymmetric FORC distribution around the $\mathrm{B}_{\mathrm{b}}=0$ line with a less visible negative region, This behavior is typical of PSD magnetite grains [Roberts et al., 2000; Muxworthy and Dunlop, 2002]. FORCs were measured at $2.5 \mathrm{mT}$ steps (AD0703 and AD0712) or $5 \mathrm{mT}$ (AD0704), with an averaging time of $500 \mathrm{~ms}$. 

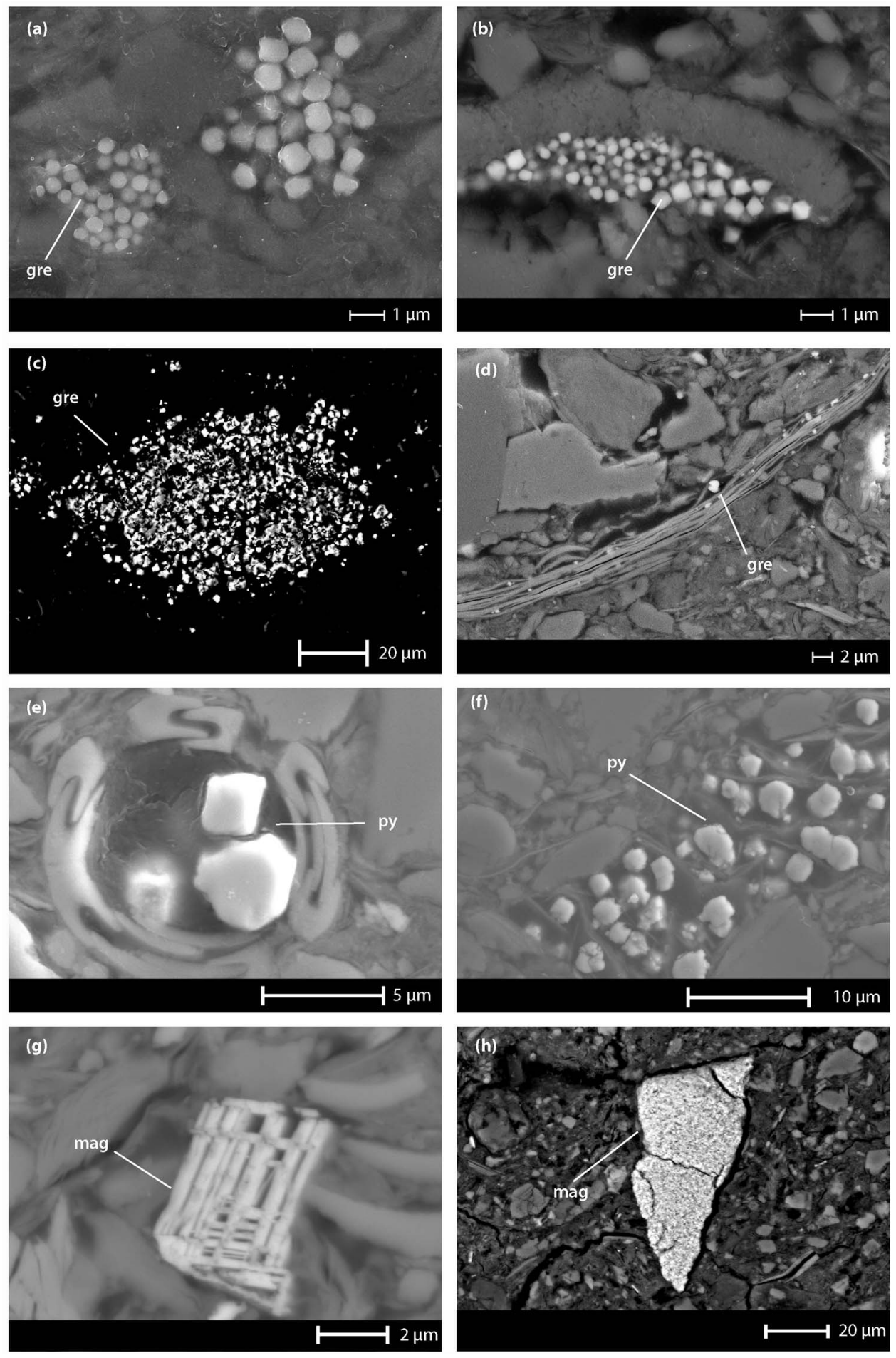

Figure 9. FE-SEM images of resin-impregnated polished thin sections from representative samples. Greigite (gre) occurs with a small grain-size within (a) framboids, (b) euhedral grain aggregates, (c) in large aggregates, or (d) as alteration of other minerals such as magnetite or silicates. (e, f) Euhedral pyrite (py) grains are also present. Detrital magnetite and titanomagnetite are characterized by (g) chemical dissolution phenomena and (h) generally occur with irregular shapes and broken edges. 
[28] As a whole, the data indicate that there are two main magnetic minerals in the Adana Basin sections. The first consists of an intermediatecoercivity phase whose remanent magnetization is completely removed between 300 and $400^{\circ} \mathrm{C}$; it is related to the presence of greigite (Fe3S4), which undergoes chemical decomposition in this temperature range [e.g., Reynolds et al., 1994; Roberts, 1995; Torii et al., 1996; Dekkers et al., 2000; Chang et al., 2008; Roberts et al., 2011]. Furthermore, acquisition of a GRM during AF demagnetization of the NRM is also a characteristic feature of SD greigite-bearing sediments [Snowball, 1997a, 1997b; Sagnotti and Winkler, 1999; Stephenson and Snowball, 2001; Roberts et al., 2011]. The observed magnetic alteration during heating (Figure 2e), with production of new highly magnetic minerals at $\mathrm{T}>300-350^{\circ} \mathrm{C}$ is compatible with the thermal breakdown of paramagnetic pyrite, which oxidizes to magnetite during heating in air [Krs et al., 1992; Reynolds et al., 1994; Roberts, 1995; Dekkers et al., 2000; Chang et al., 2008]. The second magnetic mineral consists of a low-coercivity phase with maximum unblocking temperature of $530-580^{\circ} \mathrm{C}$. This mineral is magnetite $\left(\mathrm{Fe}_{3} \mathrm{O}_{4}\right)$, whose presence is compatible with the absence of GRM during AF demagnetization of the NRM, and with the absence of significant changes in magnetic susceptibility during heating (Figures 2a and 2c).

\subsection{SEM and FE-SEM Observation and Analyses}

[29] Microtextures of representative samples were investigated using backscattered electron (BSE) imaging of polished sections from the sampled units. Optical analyses confirm the presence of ironsulfides and magnetite. Iron-sulfides occur both as closely packed aggregates of cubo-octahedral crystals with uniform shape and submicron size surrounded by the clay matrix (Figures 9a and 9b) and as individual euhedral crystals dispersed within the clay matrix or within phyllosilicate sheets (Figures 9c and 9d). The iron-sulfide aggregates have different forms and dimensions. In most cases aggregates form sub-spherical framboids (Figure 9a), or are concentrated in elongated patches (Figure 9b), whereas in other cases they have irregular distributions (Figure 9c).

[30] The composition of iron sulfide grains has been determined by EDS analysis, which demonstrates the presence of both pyrite $(\mathrm{Fe} / \mathrm{S}=0.5)$ and greigite $(\mathrm{Fe} / \mathrm{S}=0.75)$ [Roberts and Weaver, 2005]. Greigite is generally characterized by smaller grains with respect to pyrite. In Figure 9 several examples are reported, where finer-grained greigite crystals $(\sim 0.5 \mu \mathrm{m})$ are shown within aggregates (Figures $9 \mathrm{a}$ and $9 \mathrm{~b}$ ), or as single crystals dispersed within single phyllosilicate minerals (Figure 9d). Greigite grain sizes in the submicron range are compatible with the SD-type properties suggested by rock magnetic properties (i.e., GRM acquisition, FORC distributions [see Roberts et al., 2011]). Pyrite usually occurs as larger size grains $(1-2 \mu \mathrm{m})$ with respect to greigite, and has been recognized as single crystals filling space inside coccoliths (Figure 9e) or within larger iron-sulfide aggregates (Figure 9f).

[31] Magnetite and titano-magnetite grains have also been recognized, and are characterized by large grain sizes, even larger than $10 \mu \mathrm{m}$ (Figures 9g and 9h). In a few cases, we recognized prismatic minerals with regular shapes and evidence of alteration and chemical dissolution (Figure 9g). In most cases, magnetite grains have irregular shape with broken edges that indicate a detrital origin (Figure 9h). No magnetite grains of micron or submicron size were observed in our SEM and FE-SEM imaging.

\section{Discussion}

\subsection{Inconsistent Magnetic Polarities of the Analyzed Sediments}

[32] The accepted age model for the MSC [Krijgsman et al., 1999] and recent findings in Messinian deposits of the Adana Basin [Cosentino et al., 2010a, 2010b; Cipollari et al., 2012] provide a basis for a high-resolution stratigraphy of the Messinian units of the Adana Basin. In this framework, all of the analyzed samples are younger than the MES, which is astronomically dated at $5.59 \mathrm{Ma}$ [Krijgsman et al., 1999], and older than the Messinian/Zanclean transition (5.332 Ma [Lourens et al., 1996, 2004]) which is recognized in the Adana Basin to the south of the analyzed sections (Avadan section [Cipollari et al., 2012]). This age model implies that all of the analyzed samples were deposited within subchron C3r (6.033-5.235 Ma [Lourens et al., 2004]), which encompasses all of the Messinian events related to the MSC. From this age constraint, we expect all of the studied samples to have a reversed polarity ChRM. Conversely, paleomagnetic results have a large number of normal and reversed polarity zones (Figure 3). In addition, contradictory magnetic polarities are recorded at single stratigraphic levels, with some samples retaining polarities that are opposite to those recorded by sister samples [Jiang et al., 2001]. 


\subsection{Influence of Magnetic Mineralogy on the Distribution of Magnetic Polarity Zones}

[33] A complex magnetic mineralogy has been found in all of the studied sections, which are characterized by a variable mixture of two main magnetic carriers: greigite and magnetite. These two minerals have been found together in many marine and lacustrine sequences either in the Mediterranean Basin or in other areas around the world [e.g., Roberts et al., 1996; Horng et al., 1998; Reynolds et al., 1999; Roberts et al., 1999; Sagnotti and Winkler, 1999; Kao et al., 2004; Sagnotti et al., 2005; Rowan and Roberts, 2006; Babinszki et al., 2007; Ron et al., 2007; Vasiliev et al., 2007; Fu et al., 2008; Porreca et al., 2009]. In many cases, a clear relationship has been pointed out between the magnetic polarity distribution and the occurrence of greigite or magnetite within sediments [e.g., Horng et al., 1998; Jiang et al., 2001; Sagnotti et al., 2005]. We therefore analyzed a series of rock magnetic parameters to distinguish between magnetite and greigite, in order to test whether there is a mineralogical control on the magnetic polarity distribution. In particular, we used the following parameters: a) $\mathrm{MDF}_{\mathrm{NRM}}$ (median destructive field of the NRM), calculated for samples subjected to stepwise AF demagnetization using the value of the peak AF that reduces the NRM intensity to $1 / 2$ of its initial value; b) $\Delta \mathrm{GRM} / \Delta \mathrm{NRM}$, which is calculated following the method of $F u$ et al. [2008], where $\Delta$ GRM represents the ratio between the final NRM measured after the last AF demagnetization step and the minimum NRM value during the whole AF treatment, whereas $\triangle \mathrm{NRM}$ represents the ratio of initial NRM value and the minimum NRM value; and c) $B_{C R} / B_{C}$. A clear distinction is evident between normal polarity and reversed polarity samples (Figure 10), which suggests a link between magnetic mineralogy and polarity in the studied sediments. In particular, reversed polarity samples typically have intermediate-coercivity magnetic minerals $\left(\mathrm{B}_{\mathrm{C}}\right.$ values between 40 and $\left.80 \mathrm{mT}\right)$, which could be due to greigite, given that these samples usually have higher values of MDF ( $>20 \mathrm{mT}$ ), higher values of $\Delta \mathrm{GRM} / \triangle \mathrm{NRM}$ because of the acquisition of GRM during AF demagnetization, and $\mathrm{B}_{\mathrm{CR}} / \mathrm{B}_{\mathrm{C}}$ values less than 3 . On the contrary, normal polarity samples are characterized by low coercitivity minerals and no GRM acquisition, which suggest the prevalence of PSD and MD magnetite. These results strongly indicate that the distribution of the magnetic polarity zones is controlled by the relative abundance of magnetite or greigite within the Adana Basin sections. In particular, most normal polarity samples contain magnetite, whereas for reversed polarity samples, greigite is the main magnetic carrier. This implies that magnetite and greigite acquired their magnetization at different times.

\subsection{Tectonic and Paleomagnetic Constraints on the Magnetization Acquisition}

[34] Results from reversal and fold tests and the presence of slumps within the MEN0 section allow us to constrain the relative timing of remanence acquisition for greigite and magnetite. Reversal tests for the sampled sections were negative, which indicates that normal and reversed polarity ChRM directions are not antipodal. The mean direction for the normal polarity samples is close to the present-day GAD direction expected at the sampling sites. Furthermore, the distribution of normal polarity directions increases its dispersion when the tectonic bedding correction is applied, which results in a negative fold test. These results indicate that the normal polarity samples acquired their magnetization after tectonic tilting of the sequences. The reversed polarity samples are, in geographic coordinates, quite far from the GAD directions expected for a reversed polarity field, with greater scatter before rather than after tectonic correction. As a consequence, the reversed polarity samples acquired their magnetization before tectonic tilting. Furthermore, the reversed polarity samples from the MEN0 section acquired their magnetization after slump formation, as indicated by the better grouping of the ChRM directions before rather than after application of the bedding correction. The reversed polarity paleomagnetic data also indicate that the Adana Basin underwent $14^{\circ} \pm 5^{\circ}$ of counterclockwise rotation since the time of this ChRM acquisition.

[35] AMS results indicate a magnetic fabric that is typical of clayey sediments at the earliest stages of deformation [Larrasoaña et al., 2011]. The magnetic foliation is sub-parallel to bedding, which suggests a primary sedimentary magnetic fabric. The magnetic lineation has a mean direction that is oriented NNE-SSW, which is almost orthogonal to the E-W oriented normal faults in the sampled sections. This relationship between magnetic lineation and normal faults has been already observed in several Neogene extensional basins in the Mediterranean area [Mattei et al., 2004; Cifelli et al., 2004a, 2007], and is considered to have a tectonic origin. In this interpretation the tectonic lineation may arise as an intersection lineation of differently oriented basal planes of the clay minerals, which 

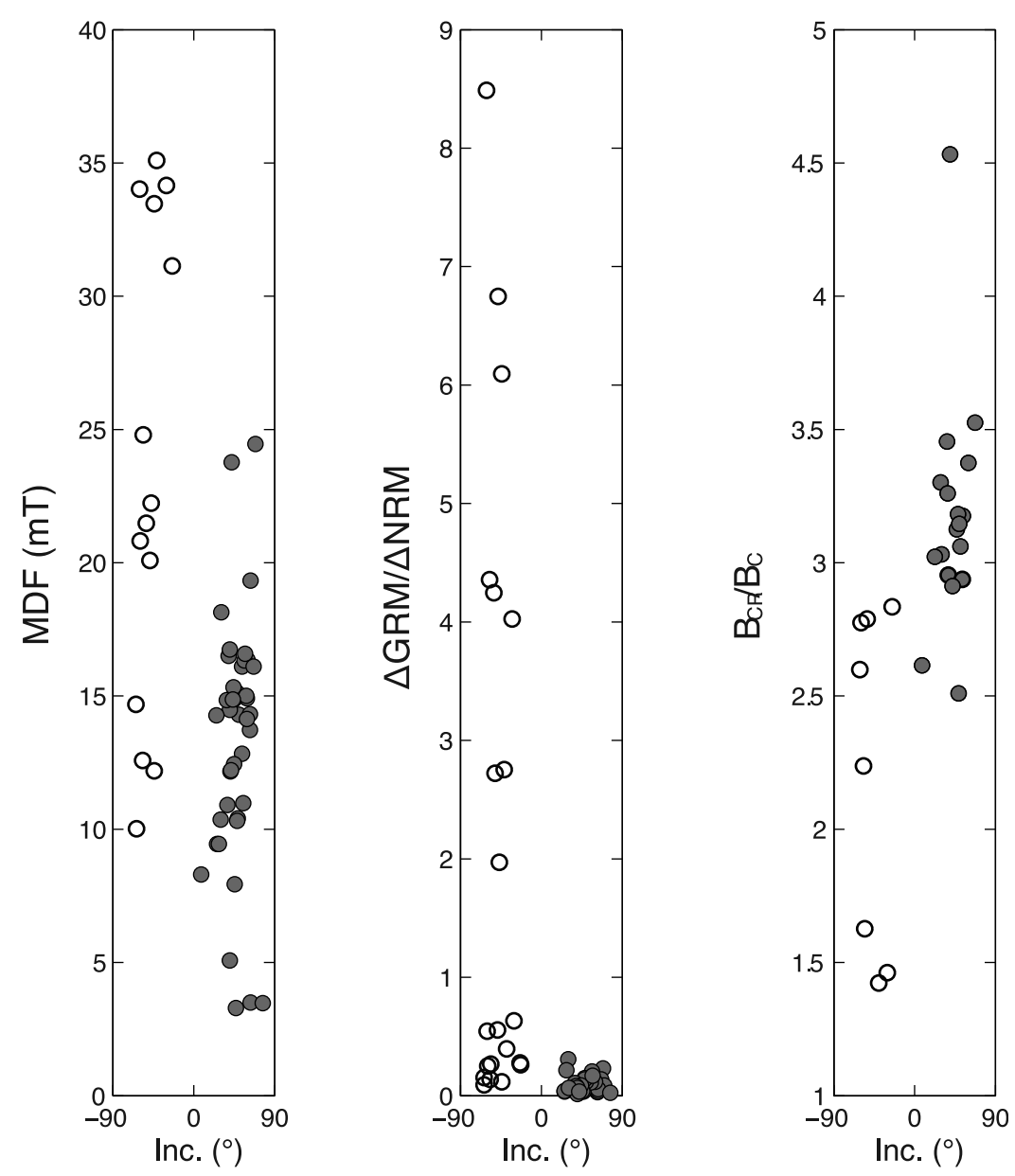

Figure 10. Comparison of ChRM inclination (Inc.) values with rock magnetic parameters for the AD01-02-03 section. (left) $\mathrm{MDF}_{\mathrm{NRM}}$ versus Inc.; (middle) $\Delta \mathrm{GRM} / \Delta \mathrm{NRM}$ versus Inc.; (right) $\mathrm{B}_{\mathrm{CR}} / \mathrm{B}_{\mathrm{C}}$ versus Inc. (see text for explanation). Open and closed circles indicate reversed and normal polarities, respectively.

reflects the orientation of their common axes [Cifelli et al., 2004b, 2005].

\subsection{A Hypothesis for the Timing of Remanence Acquisition}

[36] Using these tectonic and paleomagnetic constraints, it is possible to reconstruct the timing of magnetization of the different magnetic minerals. In Figure 11 we schematically summarize the different magnetization events that occurred in the upper Messinian units of the Adana Basin, taking into account paleomagnetic results, SEM observations and the tectono-sedimentary evolution of the basin. Evidence for the presence of large detrital magnetite grains suggests that during deposition of the Upper Messinian sedimentary units of the Adana Basin a detrital remanent magnetization (DRM) was initially acquired, which would have been the primary magnetization (step 1 in Figure 11). This primary ChRM, which was carried by magnetically stable detrital magnetite grains, has been rarely preserved along the entire section and is only evident in a few magnetite-bearing samples (Figures $2 \mathrm{~g}$ and $2 \mathrm{~h}$ ) with reversed polarity.

[37] An earlier secondary magnetization is related to diagenetic growth of greigite. Greigite can form authigenically in anoxic sedimentary environments as an intermediate product in the chemical pathway to pyrite formation. Reducing diagenetic environments, which dominated the Adana Basin during the late Messinian, will give rise to pyrite formation, which results from microbial degradation of organic matter and bacterial sulfate reduction [Berner, 1984]. Dissolved sulfide is produced by these reactions, which reacts with detrital iron-bearing minerals to form iron sulfides. SEM and magnetic mineralogy analyses indicate that the studied sediments contain greigite, pyrite, silicates and ilmenite (Figure 9), which are either the product of sulfidization or are resistant to it [Berner, 1970; Roberts and Turner, 
Late Messinian

Step 1:
Deposition of magnetite grains and
acquisition of a detrital remanent
magnetization during Chron C3r
(reversed polarity epoch).

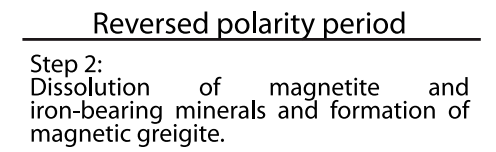

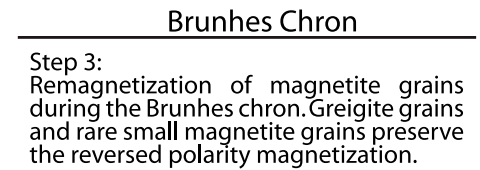

.
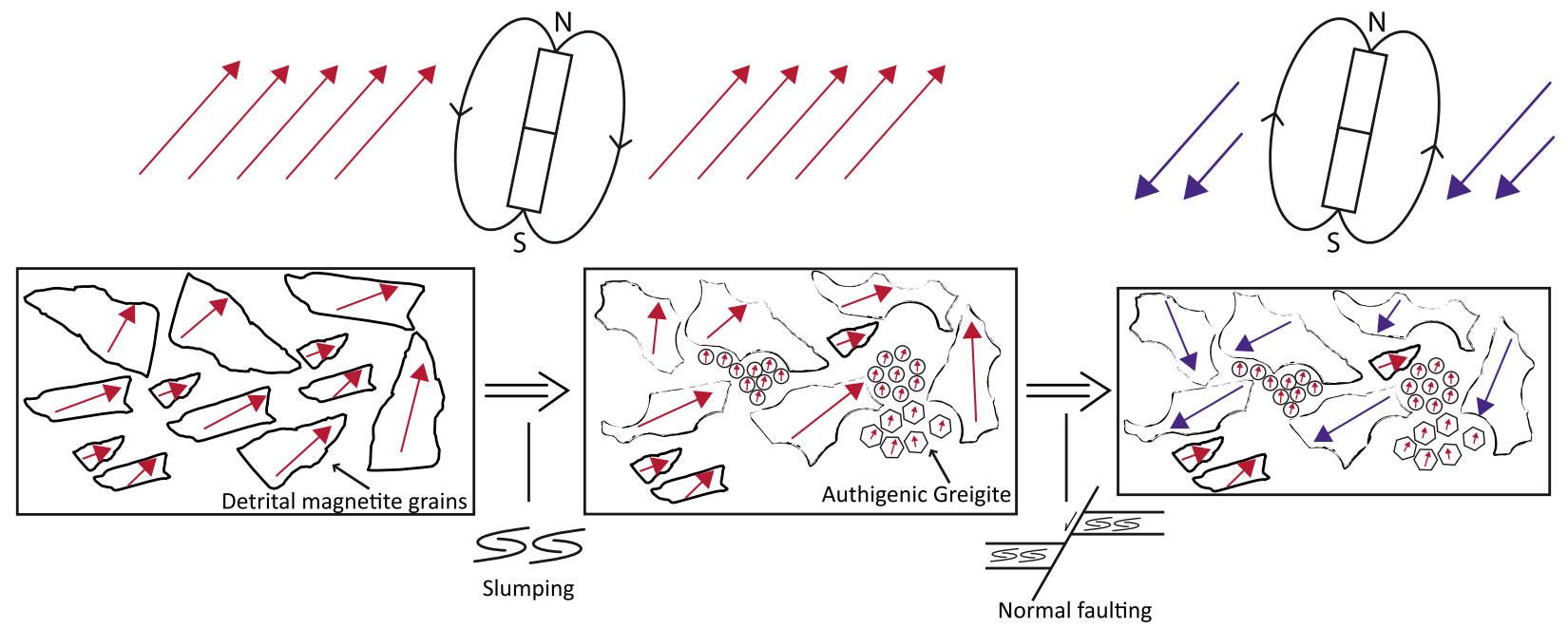

Figure 11. A hypothesized reconstruction of the timing of remanence acquisition for the different mineral phases in the studied sedimentary sequences.

1993; Wilkin and Barnes, 1997; Benning et al., 2000; Nowaczyk, 2011]. Most of the observed titanomagnetites, magnetite, and iron-bearing silicates contain evidence of dissolution. The iron released from the dissolved minerals is likely to have been used to form iron sulfides. Greigite is often present in association with pyrite [Berner, 1970, 1984; Roberts and Turner, 1993; Roberts and Weaver, 2005]. On the basis of these observations, we deduce that diagenetic dissolution has virtually destroyed the primary remanence carried by detrital magnetite, and that greigite, which formed from the released iron, is the main carrier of the remaining secondary magnetization. These processes occurred after a period of tectonic instability in the basin, which was responsible for slump formation before the sediments completely lithified and before the beginning of normal fault activity. Growth of ferrimagnetic iron sulfides is represented in the studied section by greigite-bearing samples with reversed polarity (Figures $2 \mathrm{e}$ and $2 \mathrm{f}$ and step 2 in Figure 11). Most likely acquisition of this reversed polarity component carried by greigite was not greatly delayed with respect to deposition of the sequences and was probably acquired during subchron C3r, but we cannot exclude that it was acquired at a later time, during any of the reversed polarity intervals that predate the Brunhes Chron. A second episode of magnetic overprinting is related to the presence of normal polarity magnetite-bearing samples (Figures 2a-2d and Figure 11, step 3). This magnetic overprint formed after tectonic tilting of bedding, as demonstrated by the negative fold test, during a normal polarity epoch. Magnetite grains, on the base of SEM observations, generally have a detrital origin, large grain sizes (from 5 to $20 \mu \mathrm{m}$ ), and evidence of partial dissolution (Figures $9 \mathrm{~g}$ and $9 \mathrm{~h})$. Large grain size is compatible with MD behavior for magnetite and an unstable magnetization, which would give rise to VRM acquisition during the Brunhes Chron (Figures 2a and 2c). However, all samples in which magnetite is the main magnetic carrier have hysteresis properties typical of PSD grains or mixtures of SD and MD grains (Figures 7f). Such mixing influences hysteresis ratios [Dunlop, 2002]. These observations could explain the distribution of blocking temperatures in the demagnetization diagrams shown in Figures $2 \mathrm{a}$ and 2c. The samples either have unblocking temperatures compatible with a normal polarity VRM component $\left(180^{\circ}-330^{\circ} \mathrm{C}\right)$ carried by MD grains or a high temperature component (up to $580^{\circ} \mathrm{C}$ ), also with normal polarity, carried by small magnetite grains that formed after tectonic tilting.

\subsection{Complexity of Magnetostratigraphic Reconstructions in Young Magnetite- and Greigite-Bearing Sediments}

[38] Paleomagnetic results from the Adana Basin sections confirm that the presence of different 
magnetic minerals such as greigite and magnetite can be problematic for magnetostratigraphic studies of fine-grained sedimentary successions. Greigite carries a chemical remanent magnetization (CRM) that may be significantly younger than the host sediments [e.g., Florindo and Sagnotti, 1995; Thompson and Cameron, 1995; Horng et al., 1998; Richter et al., 1998; Jiang et al., 2001; Sagnotti et al., 2005; Rowan and Roberts, 2008; Porreca et al., 2009]. In the Adana Basin, later greigite formation could be related to migration of sulfate from evaporitic deposits of both the Lower Evaporites and the Resedimented Lower Evaporites, which crop out extensively in the basin (Gökkuyu Member of the Handere Formation), and have been drilled by a large number of industrial wells in the area [Aksu et al., 2005b]. Furthermore, as a consequence of complete closure of the Gibraltar Strait at around 5.59 Ma [CIESM, 2008], the Mediterranean Basin was characterized by restricted circulation of Mediterranean waters as testified by the occurrence of well laminated and unfossiliferous early postevaporitic deposits throughout the Basin [Sampalmieri et al., 2010]. The presence of authigenic barite, small authigenic framboidal pyrite, and high $U$ contents indicate persistent anoxic conditions during the early post-evaporitic Messinian stage in the Mediterranean Sea [Sampalmieri et al., 2010]. Postevaporitic sediments of the Mediterranean Basin are rich in organic matter and are generally barren in benthic biota, conditions that are indicative of low-oxygen bottom waters [Emerson and Hedges, 1988].

[39] The main difficulty in interpreting paleomagnetic data from the Adana Basin is related to the presence of different populations of magnetite grains. Few samples preserve the reversed polarity primary magnetization, which is carried by small detrital magnetite grains. In most cases, magnetite has normal polarity, which is related to a late viscous magnetization and to a secondary magnetization. We suggest that this secondary magnetic overprint is related to late-diagenetic growth of fine-grained magnetite particles, due to fluid migration or to oxygenation of the sediments. This would be compatible with the observed spectrum of unblocking temperatures, even if fine-grained magnetite grains were not observed during SEM analyses.

\section{Conclusions}

[40] Upper Messinian sediments of the Adana Basin, which were deposited during the MSC (within subchron $\mathrm{C} 3 \mathrm{r}$ ), are characterized by an inconsistent polarity record, which is related to a complex mixture of magnetite and greigite that hinders determination of a reliable magnetic polarity stratigraphy. Three classes of samples have been recognized on the basis of paleomagnetic results. The first class is characterized by a single component of magnetization, with normal polarity, which is stable up to $530-580^{\circ} \mathrm{C}$ and is related to magnetite. We interpret this magnetization as a magnetic overprint acquired during a normal polarity Chron. This overprint could be the result of a prevalent VRM acquired during the Brunhes Chron by large, magnetically unstable MD magnetite grains, which would responsible for remanence fraction removed below $250^{\circ} \mathrm{C}$ (at which temperature the NRM intensity is reduced to about 15 $20 \%$ ) together with a component that is stable at higher temperatures carried by fine-grained magnetite that grew during later diagenesis. The second class of samples is characterized by a single magnetization component, with reversed polarity, which is stable up to $330-420^{\circ} \mathrm{C}$. This magnetization is due to greigite that formed after sediment slumping and before tectonic tilting of the studied strata. The third class of samples is characterized by a reversed polarity magnetization, which is stable up to $530-580^{\circ} \mathrm{C}$. We interpret this component as a primary magnetization carried by fine-grained and magnetically stable detrital magnetite grains. Our results indicate that in the Adana Basin the general assumption that a primary magnetization will be carried by magnetite, and that greigite will carry a magnetic overprint, does not apply because a late paleomagnetic overprint has also been found for magnetite-bearing samples. Our data illustrate the complexity of magnetostratigraphic reconstructions in sequences containing variable mixtures of magnetic minerals with different magnetic stabilities that formed at different stages. We demonstrate the need to perform detailed magnetic mineralogy analyses when conducting magnetostratigraphic studies of clay-rich sediments from marine or lacustrine environments.

\section{Acknowledgments}

[41] This work is part of the Vertical Anatolian Movements Project (VAMP), funded by the TOPOEUROPE initiative of the European Science Foundation, including contributions by the Istituto di Geologia Ambientale e Geoingegneria del Consiglio Nazionale delle Ricerche (IGAG-CNR) (com. TA.P05.009, mod. TA.P05.009.003). The Ministero Istruzione Università Ricerca (MIUR), through PRIN_2008 (grant 2008HMHYFP 
M. Mattei), supported part of this work. S.L. benefited from Visiting Research Fellowships from the Institute for Rock Magnetism, which is funded by the Instruments and Facilities Program, Earth Sciences Division, National Science Foundation, and the W. Keck Foundation.

\section{References}

Aksu, A. E., J. Hall, and C. Yaltirak (2005a), Miocene to Recent tectonic evolution of the eastern Mediterranean: New pieces of the old Mediterranean puzzle, Mar. Geol., 221, 1-13, doi:10.1016/j.margeo.2005.03.014.

Aksu, A. E., T. Calon, J. Hall, S. Mansfield, and D. Yasar (2005b), The Cilicia-Adana basin complex, Eastern Mediterranean: Neogene evolution of an active fore-arc basin in an obliquely convergent margin, Mar. Geol., 221, 121-159, doi:10.1016/j.margeo.2005.03.011.

Babinszki, E., E. Márton, P. Márton, and L. F. Kiss (2007), Widespread occurrence of greigite in the sediments of Lake Pannon: Implications for environment and magnetostratigraphy, Palaeogeogr. Palaeoclimatol. Palaeoecol., 252, 626-636, doi:10.1016/j.palaeo.2007.06.001.

Benning, L. G., R. T. Wilkin, and H. L. Barnes (2000), Reaction pathways in the $\mathrm{Fe}-\mathrm{S}$ system below $100^{\circ} \mathrm{C}$, Chem. Geol., 167, 25-51, doi:10.1016/S0009-2541(99)00198-9.

Berner, R. A. (1969), Migration of iron and sulfur within anaerobic sediments during early diagenesis, Am. J. Sci, 267, 19-42, doi:10.2475/ajs.267.1.19.

Berner, R. A. (1970), Sedimentary pyrite formation, Am. J. Sci., 268, 1-23, doi:10.2475/ajs.268.1.1.

Berner, R. A. (1984), Sedimentary pyrite formation: An update, Geochim. Cosmochim. Acta, 48, 605-615, doi:10.1016/00167037(84)90089-9.

Borradaile, G., J. Mothersill, D. Tarling, and C. Alford (1986), Sources of magnetic susceptibility in a slate, Earth Planet. Sci. Lett., 76, 336-340, doi:10.1016/0012-821X(86)90084-1.

Canfield, D. E., and R. A. Berner (1987), Dissolution and pyritization of magnetite in anoxic marine sediments, Geochim. Cosmochim. Acta, 51, 645-659, doi:10.1016/0016-7037(87) 90076-7.

Chang, L., A. P. Roberts, Y. Tang, B. D. Rainford, A. R. Muxworthy, and Q. Chen (2008), Fundamental magnetic parameters from pure synthetic greigite $\left(\mathrm{Fe}_{3} \mathrm{~S}_{4}\right), J$. Geophys. Res., 113, B06104, doi:10.1029/2007JB005502.

CIESM (2008), The Messinian Salinity Crisis: From MegaDeposits to Microbiology, CIESM Workshop Monogr., vol. 33, Monaco.

Cifelli, F., M. Mattei, A. M. Hirt, and A. Gunther (2004a), The origin of tectonic fabrics in "undeformed" clays: The early stages of deformation in extensional sedimentary basins, Geophys. Res. Lett., 31, L09604, doi:10.1029/2004GL019609.

Cifelli, F., F. Rossetti, M. Mattei, A. M. Hirt, R. Funiciello, and L. Tortorici (2004b), An AMS, structural and paleomagnetic study of Quaternary deformation in eastern Sicily, J. Struct. Geol., 26, 29-46, doi:10.1016/S0191-8141(03)00092-0.

Cifelli, F., M. Mattei, M. Chadima, A. M. Hirt, and A. Hansen (2005), The origin of the tectonic lineation in extensional basins: Combined neutron texture and magnetic analysis on "undeformed" clays, Earth Planet. Sci. Lett., 235, 62-78.

Cifelli, F., F. Rossetti, and M. Mattei (2007), The architecture of brittle postorogenic extension: Results from an integrated structural and paleomagnetic study in north Calabria (southern Italy), Geol. Soc. Am. Bull., 119, 221-239, doi:10.1130/ B25900.1.
Cifelli, F., M. Mattei, M. Chadima, S. Lenser, and A. M. Hirt (2009), The magnetic fabric in "undeformed clays": AMS and neutron texture analyses from the Rif Chain (Morocco), Tectonophysics, 466, 79-88, doi:10.1016/j.tecto.2008.08.008.

Cipollari, P., et al. (2012), Easternmost Mediterranean evidence of the Zanclean flooding event and subsequent surface uplift, Adana Basin, Southern Turkey, Geol. Soc. Spec. Publ., doi:10.1144/SP372.5, in press.

Cosentino, D., G. Darbaş, and K. Gürbüz (2010a), The Messinian salinity crisis in the marginal basins of the peri-Mediterranean orogenic systems: Examples from the central Apennines (Italy) and the Adana Basin (Turkey), Geophys. Res. Abstr., 12, 2462.

Cosentino, D., G. Darbaș, E. Gliozzi, F. Grossi, K. Gürbüz, and A. Nazik (2010b), How did the Messinian salinity crisis impact the Adana Basin?, paper presented at 7th International Symposium on Eastern Mediterranean Geology, Çukurova Univ., Adana, Turkey, 18-22 Oct.

Cosentino, D., G. Radeff, G. Darbaș, F. Ö. Dudas, K. Gürbüz, and T. F. Schildgen (2010c), Late Miocene geohistory of the Mut and Adana basins (southern Turkey): Insight for uplift of the southern margin of the Central Anatolia Plateau, paper presented at Tectonic Crossroads: Evolving Orogens of Eurasia-Africa-Arabia-GSA Global Meeting, Geol. Soc. Am., Ankara, Turkey, 2-4 Oct.

Cosentino, D., T. F. Schildgen, P. Cipollari, C. Faranda, E. Gliozzi, N. Hudáčková, S. Lucifora, and M. R. Strecker (2012), Late Miocene surface uplift of the southern margin of the Central Anatolian Plateau, Central Taurides, Turkey, Geol. Soc. Am. Bull., 124, 133-145, doi:10.1130/B30466.1.

Day, R., M. Fuller, and V. A. Schmidt (1977), Hysteresis properties of titanomagnetites: Grain-size and compositional dependence, Phys. Earth Planet. Inter., 13, 260-267, doi:10.1016/0031-9201(77)90108-X.

Dekkers, M. J., H. F. Passier, and M. A. A. Schoonen (2000), Magnetic properties of hydrothermally synthesized greigite $\left(\mathrm{Fe}_{3} \mathrm{~S}_{4}\right)$-II. High- and low-temperature characteristics, Geophys. J. Int., 141, 809-819, doi:10.1046/j.1365246x.2000.00129.x.

Dunlop, D. J. (2002), Theory and application of the Day plot $\left(\mathrm{M}_{\mathrm{rs}} / \mathrm{M}_{\mathrm{s}}\right.$ versus $\left.\mathrm{H}_{\mathrm{cr}} / \mathrm{H}_{\mathrm{c}}\right) 1$. Theoretical curves and tests using titanomagnetite data, J. Geophys. Res., 107(B3), 2056, doi:10.1029/2001JB000486.

Emerson, S., and J. I. Hedges (1988), Processes controlling the organic carbon content of open ocean Sediments, Paleoceanography, 3, 621-634, doi:10.1029/PA003i005p00621.

Fisher, R. (1953), Dispersion on a sphere, Proc. R. Soc. London, Ser. A, 217, 295-305, doi:10.1098/rspa.1953.0064.

Florindo, F., and L. Sagnotti (1995), Palaeomagnetism and rock magnetism in the upper Pliocene Valle Ricca (Rome, Italy) section, Geophys. J. Int., 123, 340-354, doi:10.1111/ j.1365-246X.1995.tb06858.x.

Fu, Y., T. von Dobeneck, C. Franke, D. Heslop, and S. Kasten (2008), Rock magnetic identification and geochemical process models of greigite formation in Quaternary marine sediments from the Gulf of Mexico (IODP Hole U1319A), Earth Planet. Sci. Lett., 275, 233-245, doi:10.1016/j.epsl.2008.07.034.

Gliozzi, E., D. Cosentino, G. Darbas, F. Grossi, K. Gürbüz, and A. Nazik (2010), Late Messinian ostracod biozonation: Stratigraphical constraints for the base of the Loxoconcha mülleri Zone derived from central Apennine (Italy) and Adana Basin (southern Turkey) successions, paper presented at 7th International Symposium on Eastern Mediterranean Geology, Çukurova Univ., Adana, Turkey, 18-22 Oct.

Griffin, L. D. (2002), Aridity and humidity: Two aspects of the late Miocene climate of North Africa and the Mediterranean, 
Palaeogeogr. Palaeoclimatol. Palaeoecol., 182, 65-91, doi:10.1016/S0031-0182(01)00453-9.

Grossi, F., E. Gliozzi, and D. Cosentino (2011), Paratethyan ostracod immigrants mark the biostratigraphy of the Messinian Salinity Crisis, Joannea Geol. Palaont, 11, 66-68.

Horng, C. S., M. Torii, K.-S. Shea, and S.-J. Kao (1998), Inconsistent magnetic polarities between greigite- and pyrrhotite/ magnetite-bearing marine sediments from the Tsailiao-chi section, southwestern Taiwan, Earth Planet. Sci. Lett., 164, 467-481, doi:10.1016/S0012-821X(98)00239-8.

Hsü, K. J., W. B. F. Ryan, and M. Cita (1973), Late Miocene desiccation of the Mediterranean, Nature, 242, 240-244, doi:10.1038/242240a0.

Hunger, S., and L. G. Benning (2007), Greigite: A true intermediate on the polysulfide pathway to pyrite, Geochem. Trans., 8, 1, doi:10.1186/1467-4866-8-1.

Hüsing, S., F. Hilgen, H. Abdulaziz, and W. Krijgsman (2007), Completing the Neogene geological time scale between 8.5 and 12.5 Ma, Earth Planet. Sci. Lett., 253, 340-358, doi:10.1016/j.epsl.2006.10.036.

Jelínek, V. (1981), Characterization of the magnetic fabric of rocks, Tectonophysics, 79, T63-T67, doi:10.1016/00401951(81)90110-4.

Jelínek, V., and V. Kropáček (1978), Statistical processing of anisotropy of magnetic susceptibility measured on groups of specimens, Stud. Geophys. Geod., 22, 50-62, doi:10.1007/ BF01613632.

Jiang, W. T., C. S. Horng, A. P. Roberts, and D. R. Peacor (2001), Contradictory magnetic polarities in sediments and variable timing of neoformation of authigenic greigite, Earth Planet. Sci. Lett., 193, 1-12, doi:10.1016/S0012-821X(01) 00497-6.

Kao, S.-J., C. S. Horng, A. P. Roberts, and K.-K. Liu (2004), Carbon-sulfur-iron relationships in sedimentary rocks from southwestern Taiwan: Influence of geochemical environment on greigite and pyrrhotite formation, Chem. Geol., 203, 153-168, doi:10.1016/j.chemgeo.2003.09.007.

Kirschvink, J. L. (1980), The least-squares line and plane and the analysis of palaeomagnetic data, Geophys. J. R. Astron. Soc., 62, 699-718, doi:10.1111/j.1365-246X.1980.tb02601.x.

Krijgsman, W., F. J. Hilgen, I. Raffi, F. J. Sierro, and Á. G. D. Annunzio (1999), Chronology, causes and progression of the Messinian salinity crisis, Nature, 400, 652-655, doi:10.1038/ 23231.

Krs, M., F. Novák, M. Krsová, P. Pruner, L. Kouklíková, and J. Jansa (1992), Magnetic properties and metastability of greigite-smythite mineralization in brown-coal basins of the Krušné hory Piedmont, Bohemia, Phys. Earth Planet. Inter., 70, 273-287, doi:10.1016/0031-9201(92)90194-Z.

Larrasoaña, J. C., A. P. Roberts, R. Musgrave, E. Gràcia, E. Piñero, M. Vega, and F. Martinez-Ruiz (2007), Diagenetic formation of greigite and pyrrhotite in gas hydrate marine sedimentary systems, Earth Planet. Sci. Lett., 261, 350-366, doi:10.1016/j.epsl.2007.06.032.

Larrasoaña, J. C., M. Gómez-Paccard, S. Giralt, and A. P. Roberts (2011), Rapid locking of tectonic magnetic fabrics in weakly deformed mudrocks, Tectonophysics, 507, 16-25, doi:10.1016/j.tecto.2011.05.003.

Liu, J., R. X. Zhu, A. P. Roberts, S. Q. Li, and J. H. Chang (2004), High-resolution analysis of early diagenetic effects on magnetic minerals in post-middle-Holocene continental shelf sediments from the Korea Strait, J. Geophys. Res., 109, B03103, doi:10.1029/2003JB002813.

Lourens, L. J., F. J. Hilgen, I. Raffi, and C. Vergnaud-Grazzini (1996), Early Pleistocene chronology of the Vrica Section
(Calabria, Italy), Paleoceanography, 11, 797-812, doi:10.1029/ 96PA02691

Lourens, L. J., F. J. Hilgen, J. Laskar, N. J. Shackleton, and D. Wilson (2004), The Neogene Period, in A Geological Time Scale 2004, edited by F. M. Gradstein, J. G. Ogg, and A. G. Smith, pp. 409-440, Cambridge Univ. Press, Cambridge, U. K.

Lowrie, W. (1990), Identification of ferromagnetic minerals in a rock by coercitivity and unblocking temperature properties, Geophys. Res. Lett., 17, 159-162, doi:10.1029/ GL017i002p00159.

Mattei, M., N. D’Agostino, I. Zananiri, D. Kondopoulou, S. Pavlides, and V. Spatharas (2004), Tectonic evolution of fault-bounded continental blocks: Comparison of paleomagnetic and GPS data in the Corinth and Megara basins (Greece), J. Geophys. Res., 109, B02106, doi:10.1029/ 2003JB002506.

Muxworthy, A. R., and D. J. Dunlop (2002), First-order reversal curve (FORC) diagrams for pseudo-single-domain magnetites at high temperature, Earth Planet. Sci. Lett., 203, 369-382, doi:10.1016/S0012-821X(02)00880-4.

Newell, A. J. (2005), A high-precision model of first-order reversal curve (FORC) functions for single-domain ferromagnets with uniaxial anisotropy, Geochem. Geophys. Geosyst., 6, Q05010, doi:10.1029/2004GC000877.

Nowaczyk, N. R. (2011), Dissolution of titanomagnetite and sulphidization in sediments from Lake Kinneret, Israel, Geophys. J. Int., 187, 34-44, doi:10.1111/j.1365246X.2011.05120.x.

Pike, C. R., A. P. Roberts, and K. L. Verosub (1999), Characterizing interactions in fine magnetic particle systems using first order reversal curves, J. Appl. Phys., 85, 6660-6667, doi:10.1063/1.370176.

Pike, C. R., A. P. Roberts, M. J. Dekkers, and K. L. Verosub (2001a), An investigation of multi-domain hysteresis mechanisms using FORC diagrams, Phys. Earth Planet. Inter., 126, 11-25, doi:10.1016/S0031-9201(01)00241-2.

Pike, C. R., A. P. Roberts, and K. L. Verosub (2001b), Firstorder reversal curve diagrams and thermal relaxation effects in magnetic particles, Geophys. J. Int., 145, 721-730, doi:10.1046/j.0956-540x.2001.01419.x.

Porreca, M., and M. Mattei (2010), Tectonic and environmental evolution of Quaternary intramontane basins in Southern Apennines (Italy): Insights from palaeomagnetic and rock magnetic investigations, Geophys. J. Int., 182, 682-698, doi:10.1111/j.1365-246X.2010.04661.x.

Porreca, M., M. Mattei, and G. Di Vincenzo (2009), Postdeformational growth of late diagenetic greigite in lacustrine sediments from southern Italy, Geophys. Res. Lett., 36, L09307, doi:10.1029/2009GL037350.

Reynolds, R. L., M. L. Tuttle, C. A. Rice, N. S. Fishman, J. A. Karachewski, and D. M. Sherman (1994), Magnetization and geochemistry of greigite-bearing Cretaceous strata, North Slope basin, Alaska, Am. J. Sci., 294, 485-528, doi:10.2475/ ajs.294.4.485.

Reynolds, R. L., J. G. Rosenbaum, P. V. Metre, M. Tuttle, and A. Goldin (1999), Greigite $\left(\mathrm{Fe}_{3} \mathrm{~S}_{4}\right)$ as an indicator of drought-The 1912-1994 sediment magnetic record from White Rock Lake, Dallas, Texas, USA, J. Paleolimnol., 21, 193-206, doi:10.1023/A:1008027815203.

Richter, C., A. P. Roberts, J. S. Stoner, L. D. Benning, and C. T. Chi (1998), Magnetostratigraphy of Pliocene-Pleistocene sediments from the Eastern Mediterranean Sea, Proc. Ocean Drill. Program Sci. Results, 160, 61-73. 
Roberts, A. P. (1995), Magnetic properties of sedimentary greigite $\left(\mathrm{Fe}_{3} \mathrm{~S}_{4}\right)$, Earth Planet. Sci. Lett., 134, 227-236, doi:10.1016/0012-821X(95)00131-U.

Roberts, A. P., and G. M. Turner (1993), Diagenetic formation of ferrimagnetic iron sulphide minerals in rapidly deposited marine sediments, South Island, New Zealand, Earth Planet. Sci. Lett., 115, 257-273, doi:10.1016/0012821X(93)90226-Y.

Roberts, A. P., and R. Weaver (2005), Multiple mechanisms of remagnetization involving sedimentary greigite $\left(\mathrm{Fe}_{3} \mathrm{~S}_{4}\right)$, Earth Planet. Sci. Lett., 231, 263-277, doi:10.1016/j.epsl. 2004.11.024

Roberts, A. P., R. L. Reynolds, K. L. Verosub, and D. P. Adam (1996), Environmental magnetic implications of greigite $\left(\mathrm{Fe}_{3} \mathrm{~S}_{4}\right)$ formation in a 3 million year lake sediment record from Butte Valley, Northern California, Geophys. Res. Lett., 23, 2859-2862, doi:10.1029/96GL02831.

Roberts, A. P., J. S. Stoner, and C. Richter (1999), Diagenetic magnetic enhancement of sapropels from the eastern Mediterranean Sea, Mar. Geol., 153, 103-116, doi:10.1016/ S0025-3227(98)00087-5.

Roberts, A. P., C. R. Pike, and K. L. Verosub (2000), Firstorder reversal curve diagrams: A new tool for characterizing the magnetic properties of natural samples, J. Geophys. Res., 105, 28,461-28,475, doi:10.1029/2000JB900326.

Roberts, A. P., Q. Liu, C. J. Rowan, L. Chang, C. Carvallo, J. Torrent, and C.-S. Horng (2006), Characterization of hematite $\left(\alpha-\mathrm{Fe}_{2} \mathrm{O}_{3}\right)$, goethite $(\alpha-\mathrm{FeOOH})$, greigite $\left(\mathrm{Fe}_{3} \mathrm{~S}_{4}\right)$, and pyrrhotite $\left(\mathrm{Fe}_{7} \mathrm{~S}_{8}\right)$ using first-order reversal curve diagrams, J. Geophys. Res., 111, B12S35, doi:10.1029/2006JB004715.

Roberts, A. P., L. Chang, C. J. Rowan, C. S. Horng, and F. Florindo (2011), Magnetic properties of sedimentary greigite $\left(\mathrm{Fe}_{3} \mathrm{~S}_{4}\right)$ : An update, Rev. Geophys., 49, RG1002, doi:10.1029/2010RG000336.

Robertson, A. H. F. (1998), Mesozoic-Tertiary tectonic evolution of the easternmost Mediterranean area: Integration of marine and land evidence, Proc. Ocean Drill. Program Sci. Results, 160, 723-782.

Rochette, P. (1987), Magnetic susceptibility of the rock matrix related to magnetic fabric studies, J. Struct. Geol., 9, 1015-1020, doi:10.1016/0191-8141(87)90009-5.

Ron, H., N. R. Nowaczyk, U. Frank, M. J. Schwab, R. Naumann, B. Striewski, and A. Agnon (2007), Greigite detected as dominating remanence carrier in Late Pleistocene sediments, Lisan formation, from Lake Kinneret (Sea of Galilee), Israel, Geophys. J. Int., 170, 117-131, doi:10.1111/ j.1365-246X.2007.03425.x.

Rowan, C. J., and A. P. Roberts (2006), Magnetite dissolution, diachronous greigite formation, and secondary magnetizations from pyrite oxidation: Unravelling complex magnetizations in Neogene marine sediments from New Zealand, Earth Planet. Sci. Lett., 241, 119-137, doi:10.1016/j.epsl.2005.10.017.

Rowan, C. J., and A. P. Roberts (2008), Widespread remagnetizations and a new view of Neogene tectonic rotations within the Australia-Pacific plate boundary zone, New Zealand, J. Geophys. Res., 113, B03103, doi:10.1029/2006JB004594.

Rowan, C. J., A. P. Roberts, and T. Broadbent (2009), Reductive diagenesis, magnetite dissolution, greigite growth and paleomagnetic smoothing in marine sediments: A new view, Earth Planet. Sci. Lett., 277, 223-235, doi:10.1016/j.epsl. 2008.10.016

Sagnotti, L., and A. Winkler (1999), Rock magnetism and palaeomagnetism of greigite-bearing mudstones in the Italian peninsula, Earth Planet. Sci. Lett., 165, 67-80, doi:10.1016/ S0012-821X(98)00248-9.
Sagnotti, L., F. Speranza, A. Winkler, M. Mattei, and R. Funiciello (1998), Magnetic fabric of clay sediments from the external northern Apennines (Italy), Phys. Earth Planet. Inter., 105, 73-93, doi:10.1016/S0031-9201(97)00071-X.

Sagnotti, L., A. P. Roberts, R. Weaver, K. L. Verosub, F. Florindo, C. R. Pike, T. Clayton, and G. S. Wilson (2005), Apparent magnetic polarity reversals due to remagnetization resulting from late diagenetic growth of greigite from siderite, Geophys. J. Int., 160, 89-100, doi:10.1111/j.1365246X.2005.02485.x.

Sampalmieri, G., A. Iadanza, P. Cipollari, D. Cosentino, and S. Lo Mastro (2010), Palaeoenvironments of the Mediterranean Basin at the Messinian hypersaline/hyposaline transition: Evidence from natural radioactivity and microfacies of post-evaporitic successions of the Adriatic sub-basin, Terra Nova, 22, 239-250, doi:10.1111/j.1365-3121.2010.00939.x.

Schildgen, T. F., D. Cosentino, B. Bookhagen, S. Niedermann, C. Yildirım, H. Echtler, H. Wittmann, and M. R. Strecker (2012a), Multi-phased uplift of the southern margin of the Central Anatolian plateau, Turkey: A record of tectonic and upper mantle processes, Earth Planet. Sci. Lett., 317-318, 85-95, doi:10.1016/j.eps1.2011.12.003.

Schildgen, T. F., D. Cosentino, A. Caruso, R. Buchwaldt, C. Yildırım, S. A. Bowring, B. Rojay, H. Echtler, and M. R. Strecker (2012b), Surface expression of eastern Mediterranean slab dynamics: Neogene topographic and structural evolution of the southwest margin of the Central Anatolian Plateau, Turkey, Tectonics, 31, TC2005, doi:10.1029/ $2011 \mathrm{TC} 003021$.

Snowball, I. F. (1997a), Gyroremanent magnetization and the magnetic properties of greigite-bearing clays in southern Sweden, Geophys. J. Int., 129, 624-636, doi:10.1111/ j.1365-246X.1997.tb04498.x.

Snowball, I. F. (1997b), The detection of single-domain greigite $\left(\mathrm{Fe}_{3} \mathrm{~S}_{4}\right)$ using rotational remanent magnetization (RRM) and the effective gyro field $\left(\mathrm{B}_{\mathrm{g}}\right)$ : Mineral magnetic and palaeomagnetic applications, Geophys. J. Int., 130, 704-716, doi:10.1111/j.1365-246X.1997.tb01865.x.

Stephenson, A., and I. F. Snowball (2001), A large gyromagnetic effect in greigite, Geophys. J. Int., 145, 570-575, doi:10.1046/j.0956-540x.2001.01434.x.

Tauxe, L., N. Kylstra, and C. Constable (1991), Bootstrap statistics for paleomagnetic data, J. Geophys. Res., 96, 11,723-11,740, doi:10.1029/91JB00572.

Thompson, R., and T. D. J. Cameron (1995), Palaeomagnetic study of Cenozoic sediments in North Sea boreholes: An example of a magnetostratigraphic conundrum in a hydrocarbon producing area, Geol. Soc. Spec. Publ., 98, 223-236, doi:10.1144/GSL.SP.1995.098.01.13.

Torii, M., K. Fukuma, C. S. Horng, and T. Q. Lee (1996), Magnetic discrimination of pyrrhotite- and greigite-bearing sediment samples, Geophys. Res. Lett., 23, 1813-1816, doi:10.1029/96GL01626.

Ünlügenç, U. C. (1993), Controls on Cenozoic sedimentation in the Adana Basin, southern Turkey, PhD thesis, Dep. of Earth Sciences and Geography, Keele Univ., Keele, U. K.

Vasiliev, I., M. J. Dekkers, W. Krijgsman, C. Franke, C. G. Langereis, and T. A. T. Mullender (2007), Early diagenetic greigite as a recorder of the palaeomagnetic signal in Miocene-Pliocene sedimentary rocks of the Carpathian foredeep (Romania), Geophys. J. Int., 171, 613-629, doi:10.1111/ j.1365-246X.2007.03560.x.

Vasiliev, I., C. Franke, J. D. Meeldijk, M. J. Dekkers, C. G. Langereis, and W. Krijgsman (2008), Putative greigite 
magnetofossils from the Pliocene epoch, Nat. Geosci., 1, 782-786, doi:10.1038/ngeo335.

Wilkin, R. T., and H. L. Barnes (1997), Formation processes of framboidal pyrite, Geochim. Cosmochim. Acta, 61, 323-339, doi:10.1016/S0016-7037(96)00320-1.

Winklhofer, M., and G. T. Zimanyi (2006), Extracting the intrinsic switching field distribution in perpendicular media:
A comparative analysis, J. Appl. Phys., 99, 08E710, doi:10.1063/1.2176598.

Winklhofer, M., R. K. Dumas, and K. Liu (2008), Identifying reversible and irreversible magnetization changes in prototype patterned media using first- and second-order reversal curves, J. Appl. Phys., 103, 07C518, doi:10.1063/1.2837888. 